\title{
Caracterização hidrogeológica e hidroquímica das águas subterrâneas da região de São Gabriel, RS
}

\author{
Marcelo GOFFERMANN ${ }^{1}$, Antonio P. VIERO ${ }^{2} \&$ Eliane Born da SILVA ${ }^{2}$
}

1 Programa de Pós-graduação em Geociências, Instituto de Geociências, Universidade Federal do Rio Grande do Sul. Av. Bento Gonçalves, 9500, CEP 91.540-000, Porto Alegre, RS, Brasil. E-mail: margoff@terra.com.br.

2 Instituto de Geociências, Universidade Federal do Rio Grande do Sul. Av. Bento Gonçalves, 9500, CEP 91.540-000, Porto Alegre, RS, Brasil. E-mail: antonio.viero@ufrgs.br.

2 Instituto de Geociências, Universidade Federal do Rio Grande do Sul. Av. Bento Gonçalves, 9500, CEP 91.540-000, Porto Alegre, RS, Brasil. E-mail: lili_born@yahoo.com.br.

Recebido em 08/2013. Aceito para publicação em 08/2015.

Versão online publicada em 11/12/2015 (www.pesquisasemgeociencias.ufrgs.br)

\begin{abstract}
Resumo- 0 presente estudo trata da caracterização hidrogeológica e hidroquímica das águas subterrâneas do município de São Gabriel, RS. Foram analisadas 55 amostras de água provenientes de 55 poços tubulares profundos de diversas localidades e variados contextos hidrogeológicos. A maior parte do território do município de São Gabriel é constituída por rochas sedimentares da Bacia do Paraná. Assim, os principais aquíferos possuem águas com composições químicas bastante diversificadas, refletindo variados ambientes deposicionais e composições mineralógicas. Subordinadamente, aquíferos fraturados formados por rochas granítico-gnáissicas do Escudo Sul-rio-grandense ocorrem na porção sul do município. Desta forma, a qualidade das águas subterrâneas do município varia de acordo com as condições geológicas de cada unidade aquífera e com as relações entre elas. Na área, os elementos Flúor e Sódio são os parâmetros que comprometem a utilização das águas subterrâneas para fins de consumo humano, dessedentação de animais e irrigação. Cerca de 30 \% das análises apresentam águas impróprias para consumo com relação a estes íons, conforme parâmetros máximos permitidos pelo Ministério da Saúde do Brasil. Os principais aquíferos da região, em termos quantitativos e qualitativos, são o Aquífero Rio Bonito (ARB) e o Sistema Aquífero Guarani (SAG), localizados, respectivamente, na porção sul e nordeste do município. As águas dos poços que captam destes aquíferos são de boa qualidade, potáveis e as vazões podem ser consideradas como as melhores da região .

Palavras Chave: Aquífero Rio Bonito, São Gabriel, Flúor em águas subterrâneas, Sódio em águas subterrâneas .
\end{abstract}

\begin{abstract}
HYDROGEOLOGICAL AND HYDROCHEMISTRY CHARACTERIZATION OF GROUNDWATER FROM SÃo GABRiEL REgion, RS. The present study investigates the hydrogeological and hydrochemical characterization of groundwater in the region of São Gabriel, RS. It was made 55 chemical analysis of groundwater samples collected in 55 deep wells from different locations and different hydrogeological contexts. The municipality of São Gabriel consists mainly of sedimentary rocks of the Paraná Basin. In this way the main aquifers have groundwater with very different chemical characteristics, reflecting different depositional environments and mineralogical compositions. Granitic and gneissic rocks from the Sul-rio-grandense shield comprise the fractured aquifer that occur subordinate in the southern portion of the municipality. Thus, the quality of groundwater in the region changes according to the hydrogeological conditions of each aquifer and to the relationship between them. In this area, Fluorine and Sodium are the main parameters that restrict the use of groundwater for human supply, irrigation and livestock watering. According to the maximum parameters allowed by an ordinance of the Brazilian Ministry of Health, around 30\% of the analyzed groundwater samples are inappropriate for consumption regarding to these ions. The main aquifers of the region, in quantitative and qualitative terms, are Aquifer Rio Bonito (ARB) and the Guarani Aquifer System (SAG), located respectively in the southern and northeastern portion of the county. The waters of the wells that capture these aquifers have a good quality, potable and flow rates can be regarded as best in the region.
\end{abstract}

Keywords: Rio Bonito aquifer, São Gabriel Municipality, Fluorine in groundwater, Sodium in groundwater. 


\section{Introdução}

As águas subterrâneas na região de São Gabriel abastecem os variados setores socioeconômicos locais, como propriedades rurais, agroindústrias, frigoríficos, comunidades urbanas e rurais, hotéis, postos de combustíveis, etc. Portanto, o uso deste recurso hídrico se dá de forma bastante ampla naquela região, principalmente por se tratar de uma fonte mais confiável e mais econômica, quando comparadas com os recursos hídricos superficiais. Apenas na região urbana, abastecida por rede pública, as águas subterrâneas correspondem a formas alternativas de abastecimento. Nas demais regiões do município, correspondem à principal fonte de abastecimento.

As principais atividades econômicas do município são aquelas relacionadas ao setor primário, vinculadas à agropecuária, destacando-se os plantios de arroz e soja e a criação de gado de corte. Também se destaca a ovinocultura, para produção de carne de cordeiro e de lã. 0 setor industrial é pouco desenvolvido no município, relacionado à atividade primária, como o beneficiamento de grãos e frigoríficos.

O abastecimento de água da sede municipal se dá prioritariamente pela captação no Rio Vacacaí, através de convênio entre a Prefeitura Municipal e a empresa São Gabriel Saneamento, que assumiu o controle do fornecimento de água e esgotamento sanitário em maio de 2012, substituindo a CORSAN (Companhia Riograndense de Saneamento), que até então era a responsável pelos serviços.

Embora o abastecimento público seja realizado através da captação de águas superficiais, existem dezenas de poços tubulares na sede do município, atendendo principalmente aos setores comercial e industrial (hotéis, frigoríficos, supermercados e beneficiadores de grãos).

Na zona rural, o abastecimento humano se dá quase que exclusivamente por água subterrânea, através de poços tubulares, poços escavados (tipo cacimbas) e fontes naturais. Raras são as captações de águas superficiais utilizadas para este fim. Aquelas existentes são oriundas principalmente de açudes, amplamente utilizados, principalmente, para a dessedentação de animais.

Recentemente houve um acréscimo da população rural que se abastece exclusivamente de água subterrânea. Através de Programa do Governo Federal para a implantação da Reforma Agrária, 712 famílias foram assentadas na região sul-sudeste do município, ocupando uma área de 11.080 ha. 0 abastecimento se dá exclusivamente por poços tubulares profundos, uma vez que naquela região não há recursos hídricos superficiais suficientes para esta nova demanda. Nestas áreas, dez poços novos foram implantados pelo INCRA para atender aquelas comunidades.

O presente trabalho tem como objetivo principal a caracterização hidrogeológica e hidroquímica das águas subterrâneas da região de São Gabriel, a fim de definir quais são os melhores aquíferos em termos quantitativos e principalmente qualitativos, tendo em vista que naquela região há registros da utilização de águas subterrâneas impróprias para consumo humano, em função dos altos teores de Flúor e Sódio observados em análises de águas de poços tubulares. Desta forma, um estudo se faz necessário visando à caracterização geoquímica das águas subterrâneas da região, a partir da sistematização dos dados químico-analíticos existentes em banco de dados como o Sistema de Informações de Águas Subterrâneas da CPRM Serviço Geológico do Brasil (SIAGAS- CPRM) e de dados novos gerados neste estudo, permitindo definir as condições de potabilidade, os possíveis usos e restrições destes recursos hídricos, além de investigar as razões pelas quais o Flúor e Sódio apresentam concentrações elevadas nestas águas.

Este estudo também se justifica em função de que a perfuração de poços tubulares é geralmente realizada sem os devidos controles das entradas de água nos diferentes aquíferos atravessados, o que resulta em poços que produzem águas impróprias para consumo humano, mesmo existindo aquíferos que poderiam proporcionar águas de boa qualidade. Isto se dá principalmente pela mistura de águas captadas nos diferentes aquíferos, com composições químicas distintas, em vários hidrohorizontes no mesmo poço. 0 estudo dos tipos hidroquímicos, correlacionando-os com as unidades hidroestratigráficas, permite estabelecer critérios estratigráficos para orientar novas perfurações, de modo que os resultados finais em termos de qualidade da água sejam substancialmente melhorados.

\section{2 Área, materiais e métodos}

O município de São Gabriel está situado na região Sudoeste do Rio Grande do Sul , inserido nas bacias hidrográficas Vacacaí - Vacacaí Mirim (G060), região hidrográfica do Guaíba e Santa Maria (U070), região hidrográfica do Uruguai (Figs. 1 e 2). Seu território compreende uma área de $5.019,646 \mathrm{~km}^{2}$, sendo um dos maiores municípios do estado. 


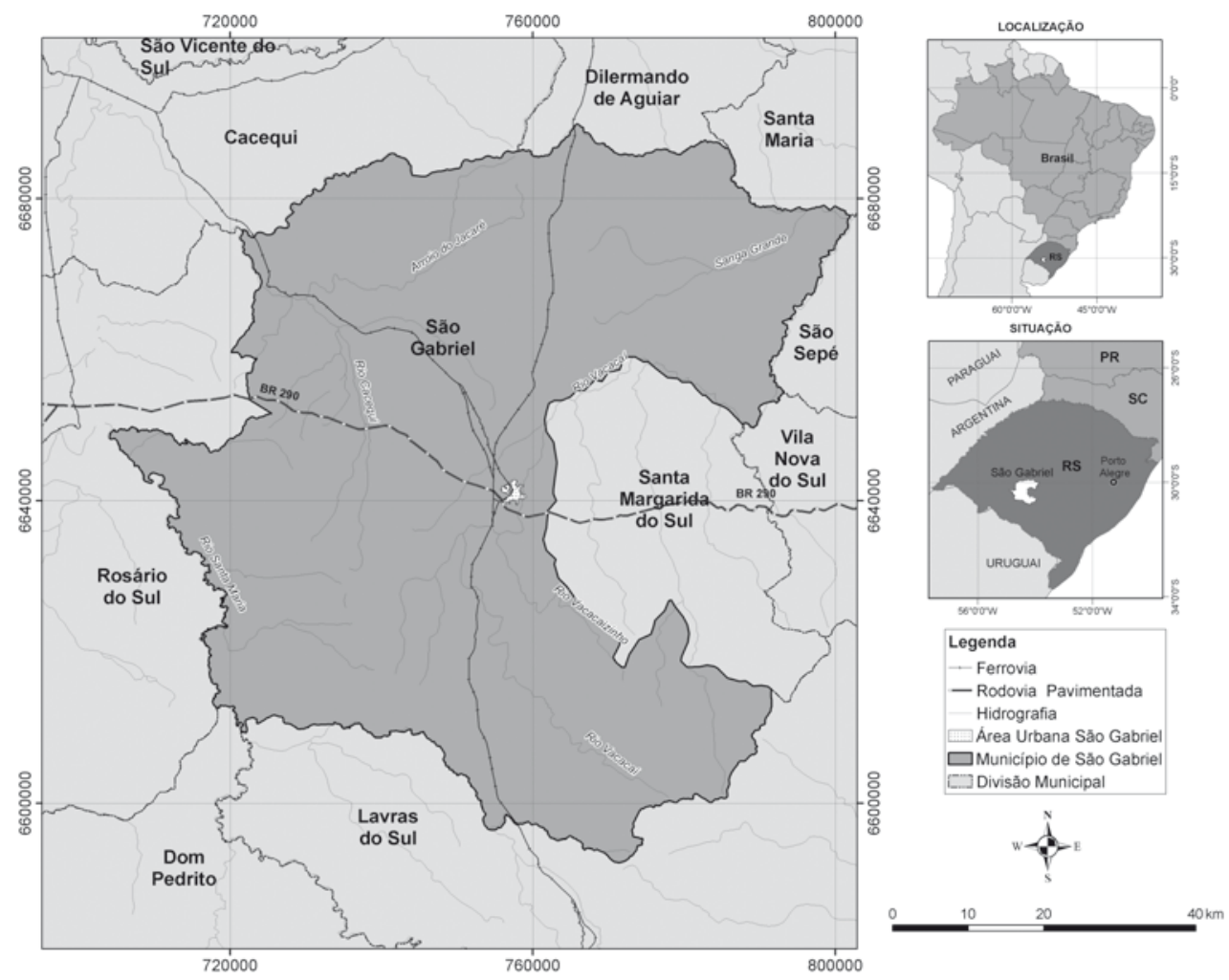

Figura 1. Localização do município de São Gabriel no estado do Rio Grande do Sul, Brasil.

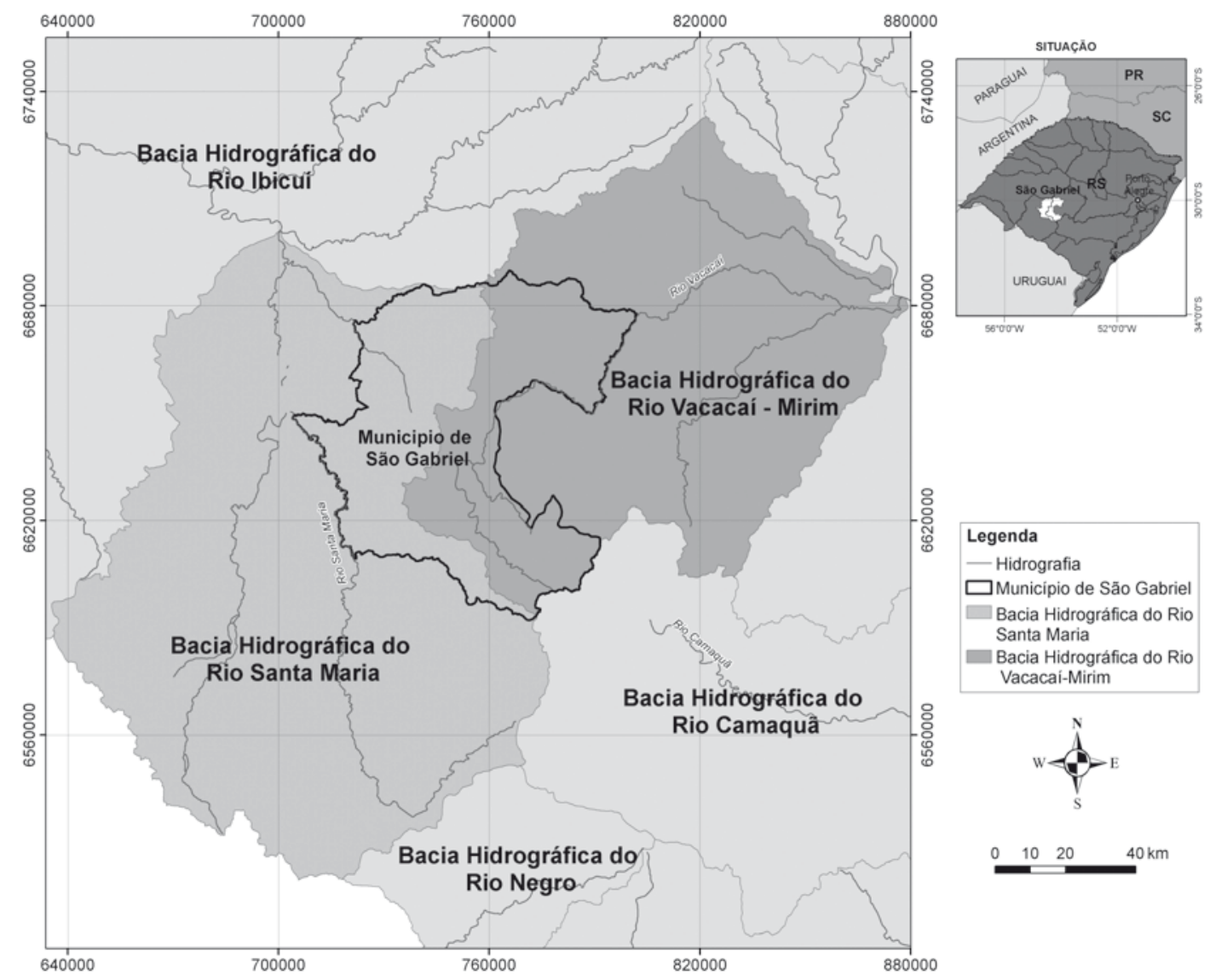

Figura 2. Bacias hidrográficas que englobam a área estudada (Santa Maria e Vacacaí - Vacacaí Mirim). 


\subsection{Contexto geológico}

O município de São Gabriel está inserido em sua maior extensão em áreas de ocorrência de rochas sedimentares da Bacia do Paraná, sendo que em sua borda sudeste predominam litologias representativas do Escudo Sul-rio-grandense (ESRG). As rochas da Bacia do Paraná pertencem aos grupos Itararé, Guatá (formações Palermo e Rio Bonito), Passa Dois (Formação Irati, Subgrupo Estrada Nova e Formação Rio do Rasto) e Formação Piramboia, conforme coluna estratigráfica proposta por Schneider et al. (1974). 0 embasamento é representado pelo Complexo Cambaí e Supercomplexo Vacacaí. A figura 3 apresenta o mapa geológico da área estudada.

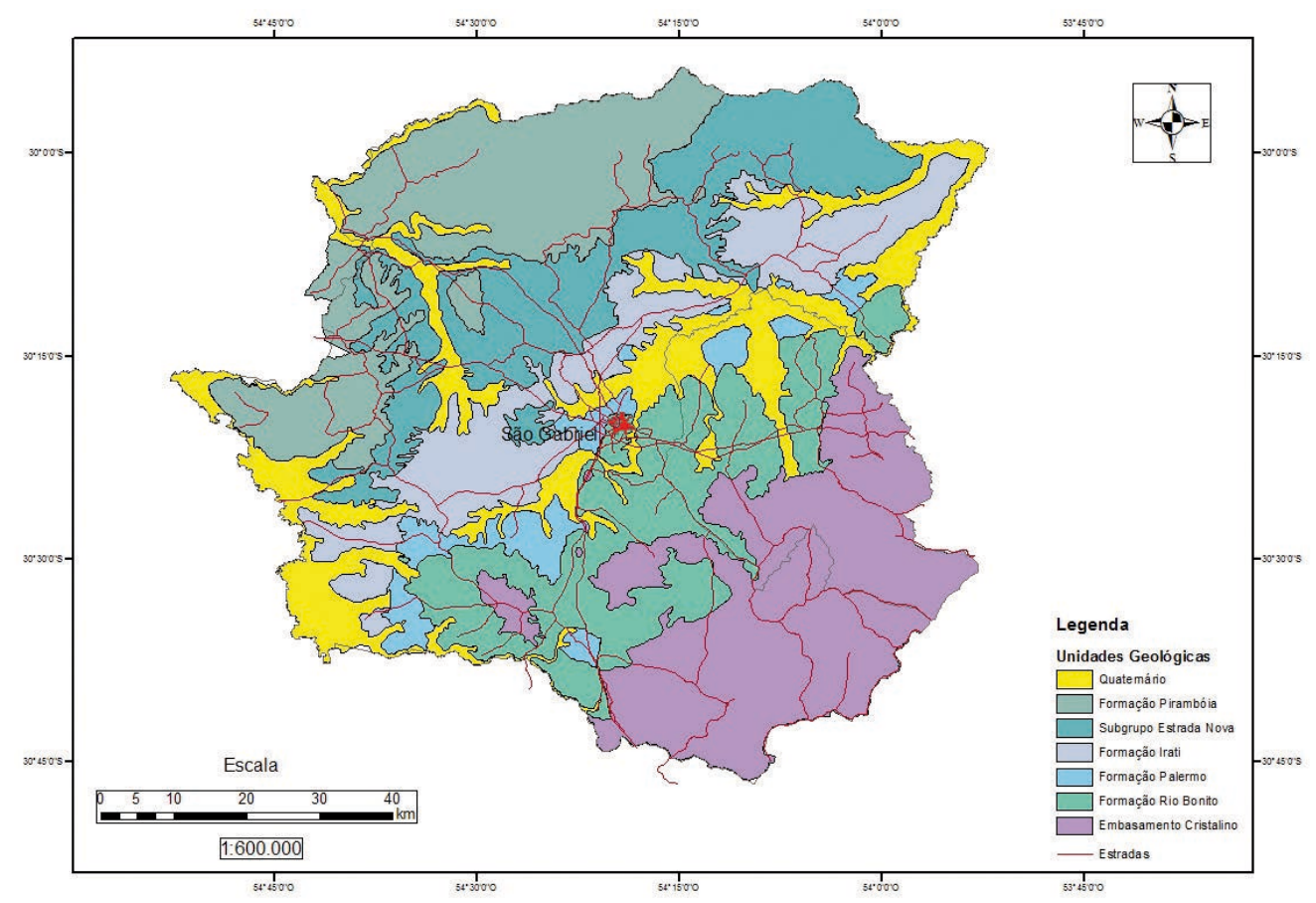

Figura 3. Mapa geológico da área estudada (adaptado de UFRGS, 1972).

\subsubsection{Escudo Sul-rio-grandense}

O Escudo Sul-rio-grandense (ESRG) está inserido na porção meridional da Província Mantiqueira (Almeida \& Hasui, 1984). Em sua porção oeste, o lineamento de Ibaré, uma estrutura regional NW-SE, separa o escudo em dois blocos: Bloco Taquarembó e Bloco São Gabriel (Naumann, 1985). O Bloco Taquarembó representaria a borda cratônica e o Bloco São Gabriel um arco magmático juvenil neoproterozoico. Os dois segmentos são afetados por intenso magmatismo e sedimentação, marcando o final do Ciclo Brasiliano.

De acordo com estas divisões propostas para a evolução geotectônico do ESRG, a área de estudo localiza-se numa parte do Bloco São Gabriel, abrangendo parcialmente o Complexo Cambaí (Silva Filho \& Soliani Jr. , 1987) e o Supercomplexo Vacacaí (Chemale Jr., 2000 ).

o Complexo Cambaí é caracterizado por uma sequência granito-gnáissica, com evolução polifásica ligada ao Ciclo Brasiliano (Silva Filho \& Soliani Jr. op.cit.), compreende gnaisses de composição monzogranítica, granodiorítica, diorítica, tonalíti- ca e trondjemítica, seguidamente recortados por rochas graníticas que muitas vezes se tornam predominantes. Os gnaisses também encontram-se intercalados com anfibolitos, metaultramafitos, metagabros, mármores e metapelitos metamorfizados na fácies anfibolito médio a superior. Também podem ser individualizados corpos isolados de sequências máfico-ultramáficas formados por anfibolitos e metaultramafitos, como harzburgitos serpentinizados e xistos magnesianos (Chemale Jr., 2000).

O Supercomplexo Vacacaí (SCV) engloba vários complexos de rochas vulcano-sedimentares deformadas e metamorfizadas em fácies xisto-verde a anfibolito inferior, cujas denominações são Complexo Passo Feio, Complexo Bossoroca/Palma e Complexo Ibaré, apresentando as seguintes sequências: i) rochas máfico-ultramáficas de caráter toleítico, representadas por xistos magnesianos, serpentinitos, metabasaltos com lentes de quartzitos (metachert), mármores e metapelitos, e ii) rochas metavulcânicas e vulcanoclásticas ácidas a básicas cálcico-alcalinas, intercaladas com rochas epiclásticas (metapelitos grafitosos, arenitos e sil- 
titos) e químicas como cherts e formações ferríferas bandadas (Chemale Jr., 2000). Ainda dentro do Supercomplexo Vacacaí pode ser englobado o Complexo Metavulcano-Sedimentar Coxilha do Batovi (CMVSCB) proposto por Schmitt (1995).

\subsubsection{Rochas sedimentares da Bacia do Paraná}

As unidades litoestratigráficas que ocorrem na área são representadas pelos grupos Itararé, Guatá e Passa Dois (Schneider et al., 1974). As litologias do Grupo Itararé ocorrem de forma muito restrita, sem continuidade física, na parte sul da área estudada. Formam lentes descontínuas, não mapeáveis na escala da figura 3 , constituídas por arenitos finos esbranquiçados, siltitos, diamictitos e ritmitos, relacionados a ambiente marinho com influência de ambiente glacial.

O Grupo Guatá é composto pelas formações Rio Bonito e Palermo. A Formação Rio Bonito é constituída por camadas de quartzoarenitos de granulação fina a média, grãos arredondados bem selecionados, cinza esbranquiçados, intercalados com siltitos cinza escuros, siltitos carbonosos e camadas de carvão (espessuras milimétricas na região de São Gabriel). As rochas da Formação Rio Bonito são interpretadas como depositadas em ambiente litorâneo transicional, composto por barreiras litorâneas, lagunas, pântanos e baías estuarinas, com ação de ondas e marés. Esta unidade aflora numa ampla extensão na parte sul-sudeste do município, em uma faixa alongada de direção NE-SW, assentada sobre as unidades Pré-cambrianas.

A Formação Palermo ocorre de forma restrita na área, composta por siltitos com intercalações de lâminas e leitos de arenitos finos a muito finos com estratificação cruzada hummocky, acumulados em ambiente marinho de plataforma rasa sob ação de ondas, e posterior transição para depósitos de costa-afora.

O Grupo Passa Dois compreende a Formação Irati, constituída na base por siltitos argilosos cinza a cinza escuro, sucedidos por camadas de calcário e folhelhos pirobetuminosos no topo, depositados em ambiente marinho raso, e pelo Subgrupo Estrada Nova, constituído por siltitos com intercalações de arenitos finos a médios de ambiente deposicional marinho de águas calmas (baixo nível de ação de ondas).

O topo das deposições dos sedimentitos da Bacia do Paraná na área estudada é constituído pelas formações Rio do Rasto e Piramboia. A primeira é constituída por pelitos e arenitos com predominância de camadas tabulares ou lenticu- lares, formadas em ambiente lacustre e por siltito tabular, arenito fino tabular ou lenticular, gerados em ambiente lacustre deltaico, eólico e raros depósitos fluviais (Wildner et al., 2007). A Formação Piramboia compreende uma ampla extensão em área na porção noroeste do município de São Gabriel, sendo composta dominantemente por arenitos finos a grossos bem selecionados, avermelhados, com estratificações cruzadas de grande porte, interpretados como depósitos de dunas eólicas (Lavina, 1991).

\subsection{Contexto hidrogeológico}

Como trabalhos hidrogeológicos em escala regional destacam-se os de Hausman (1995) e Machado \& Freitas (2005). 0 primeiro autor caracterizou as províncias hidrogeológicas do estado, subdividindo-as em subprovíncias, obtendo o Mapa das Províncias Hidrogeológicas do Rio Grande do Sul na escala 1:1.000.000. O município de São Gabriel está, portanto, incluso nas Subprovíncias Permocarbonífera (Província Gonduânica) e Cristalina (Província do Escudo). Machado \& Freitas (2005) elaboraram o primeiro mapa hidrogeológico do Rio Grande do Sul, na escala 1:750.000, definindo os principais aquíferos do estado e caracterizando suas potencialidades quantitativas e qualitativas. Conforme este mapa, a área de estudo está inserida dominantemente no Sistema Aquífero Palermo-Rio Bonito e, em menor escala, no Sistema Aquífero do Embasamento Cristalino II. No município são registrados, ainda, os Aquitardos Permianos, Sistema Aquífero Sanga do Cabral- Piramboia e pequena parte do Sistema Aquífero Embasamento Cristalino III.

\subsubsection{Sistema aquífero fraturado do Embasamento Cristalino}

As unidades hidrogeológicas correspondentes ao Sistema Aquífero Cristalino II (EC2) da área são constituídas por rochas graníticas, gnaisses, andesitos, xistos, filitos e metacalcários, localizadamente afetadas por fraturas e falhas. Os poços geralmente apresentam capacidades específicas inferiores a $0,5 \mathrm{~m}^{3} / \mathrm{h} . \mathrm{m}$, ocorrendo também poços secos. A salinidade nas áreas não cobertas por sedimentos de origem marinha são inferiores a $300 \mathrm{mg} / \mathrm{L}$ de sólidos totais dissolvidos e os poços nas rochas graníticas podem apresentar enriquecimento em Flúor (Machado \& Freitas, 2005). 0 Sistema Aquífero Cristalino III (EC3) constitui-se principalmente por granitos maciços, gnaisses, riolitos e andesitos pouco alterados. Ausência de 
fraturas interconectadas e a condição topográfica desfavorável inviabilizam a perfuração de poços tubulares. Aqueles perfurados apresentaram vazões nulas (secos) ou possuem baixas vazões (Machado \& Freitas, 2005).

\subsubsection{Aquífero Rio Bonito (ARB)}

Este aquífero está inserido no Mapa Hidrogeológico do RS como SAPRB (Machado \& Freitas, 2005), englobando todas as unidades litoestratigráficas do Grupo Guatá (formações Palermo e Rio Bonito), embora as litologias da Formação Palermo, sobrepostas, atuem mais como aquitardos, confinantes do ARB, do que propriamente como aquífero. O SAPRB é representado por arenitos finos a médios, cor cinza esbranquiçados, intercalados com camadas de siltitos argilosos e carbonosos de cor cinza escura. Em média, as capacidades específicas dos poços são inferiores a 0,5 $\mathrm{m}^{3} / \mathrm{h} . \mathrm{m}$ e a salinidade das águas varia entre 800 e $1500 \mathrm{mg} / \mathrm{L}$ de sólidos totais dissolvidos, sendo que em grandes profundidades as águas são salinas com sólidos totais dissolvidos superiores a $10.000 \mathrm{mg} / \mathrm{L}$. Desta forma, o aquífero somente possui águas potáveis com possibilidade de uso na irrigação nas regiões onde está a pequenas profundidades. Hausman (1995) atribui aos "arenitos Rio Bonito" as camadas que se comportam como aquíferas, na Subprovíncia Permocarbonífera, dentro da Província Gonduânica por ele denominada. Segundo este autor, a Subprovíncia Permocarbonífera apresenta dois aquíferos na região de São Gabriel, representados pelos arenitos da Formação Rio Bonito e pelos arenitos conglomeráticos e feldspáticos da base do Grupo Itararé, estes ocorrendo sob a forma de lentes mais ou menos extensas. Entre estes dois níveis mais porosos, siltitos, arenitos finos, ritmitos e folhelhos carbonosos, bem como algumas lentes de carvão, que se comportam como aquitardos, e principalmente como aquicludes, permitem, em alguns pontos, a interconexão por drenância dos dois horizontes acima referidos e denunciados pela qualidade das águas. Entretanto, o que se observa nos poços perfurados na região de São Gabriel, é o contato direto dos arenitos da Formação Rio Bonito com as rochas do embasamento cristalino. Apenas em quatro sondagens foram observados intervalos com sedimentitos do Grupo Itararé. Esta região também diferencia-se das demais pela inexistência de depósitos de carvão, observados em outras regiões de ocorrência do ARB, como Candiota (Roisenberg et. al., 2008) e Criciúma (Krebs, 2004; Trein, 2008).

O ARB vem sendo explotado em larga escala no RS, principalmente nas regiões de Candiota, Hulha Negra e São Gabriel (Freitas et al., 2010; Goffermann et al., 2012; Kircheim et. al., 2012). Em São Gabriel, o ARB constitui o principal aquífero e sua condição mais favorável é aquela situada na parte sudeste do município, compreendendo uma faixa alongada com direção NE-SW, onde aflora sobreposto diretamente ao sistema aquífero do embasamento cristalino. Nesta área, o ARB comporta-se como confinado a semiconfinado, com entradas de água nos poços relacionadas aos quartzoarenitos finos a médios, cinza esbranquiçados, grãos arredondados e bem selecionados, sotopostos aos folhelhos, folhelhos carbonosos e siltitos cinza. Os níveis estáticos ascendem bastante sobre as entradas de água e poços surgentes podem ocorrer em locais onde a superfície do terreno é topograficamente mais baixa que a superfície potenciométrica do aquífero confinado (Goffermann et al., 2012). As vazões dos poços explotados no ARB podem chegar a $20 \mathrm{~m}^{3} / \mathrm{h}$, variando, principalmente, em função das espessuras, grau de litificação e extensão lateral das camadas arenosas, além das fraturas abertas que interceptam estes pacotes. As capacidades específicas variam de $0,5 \mathrm{~m}^{3} / \mathrm{h} . \mathrm{m}$ a $2,0 \mathrm{~m}^{3} / \mathrm{h} . \mathrm{m}$. A espessura dos horizontes aquíferos pode chegar até 30 m (SIAGAS, CPRM; Szubert \& Toniolo, 1981). A qualidade das águas varia das zonas em que ele se encontra aflorante, próximos às zonas de recarga, para as regiões em que ele se encontra confinado pelos aquitardos permianos. No primeiro caso têm-se as concentrações dos principais cátions nas seguintes proporções: $\mathrm{Ca}^{2+}$ $>\mathrm{Na}^{+}>\mathrm{Mg}^{2+}>\mathrm{K}^{+}$. No segundo, $\mathrm{Na}^{+}>\mathrm{Ca}^{2+}>\mathrm{Mg}^{2+}>$ $\mathrm{K}^{+}$. Os ânions predominantemente são os bicarbonatos $(\mathrm{HCO})_{3}{ }^{-}$e secundariamente os sulfatos $\left(\mathrm{SO}_{4}{ }^{2-}\right.$ ), estes ocorrendo em concentrações significativas quando o ARB encontra-se sob a influência dos aquitardos.

\subsubsection{Aquitardos permianos (AP)}

Os Aquitardos permianos englobam as formações Palermo, Irati, Subgrupo Estrada Nova e Formação Rio do Rasto, constituindo-se de siltitos argilosos, argilitos cinza escuros, folhelhos pirobetuminosos e pequenas camadas de calcários e arenitos. As capacidades específicas dos poços que captam água deste sistema são normalmente baixas, inferiores a $0,1 \mathrm{~m}^{3} / \mathrm{h} . \mathrm{m}$ (Machado \& Freitas, 2005). Estas unidades estão sobrejacentes ao ARB, e, por constituírem-se essencialmente de rochas sedimentares finas, são consideradas com aquitardos, não possuindo capacidades para transmissão de água subterrânea. Entretanto, lentes calcárias, 
camadas de arenitos, planos entre os folhelhos e fraturamentos podem promover a circulação de água nestas unidades. Em função do ambiente deposicional (marinho), associados à mineralogia destas rochas, os AP podem se constituir em horizontes contaminantes do ARB, principalmente quando este está em contato com os folhelhos pirobetuminosos da Formação Irati (Hausman, 1995). Os aquitardos permianos podem atingir até $40 \mathrm{~m}$ de espessura na região de São Gabriel, conforme dados de sondagens (Szubert \& Toniolo, 1981).

\subsubsection{Sistema Aquífero Sanga do Cabral-Pirambóia (SP)}

O Sistema Aquífero Sanga do Cabral-Piramboia (SP) é o representante do Sistema Aquífero
Guarani (SAG) na região de São Gabriel. Constitui-se de camadas síltico-arenosas avermelhadas com matriz argilosa e arenitos finos a muito finos, avermelhados, com cimento calcífero. As capacidades específicas são muito variáveis, em geral entre 0,5 e $1,5 \mathrm{~m}^{3} / \mathrm{h} . \mathrm{m}$. A salinidade varia de $100 \mathrm{mg} / \mathrm{L}$ nas áreas aflorantes a mais de $300 \mathrm{mg} / \mathrm{L}$ quando o aquífero encontra-se confinado. No município estudado, compreende uma área extensa com orientação NE-SW, situada na porção noroeste do mesmo. A produtividade dos poços aumenta sempre onde são perfurados em locais que interceptam camadas de arenitos eólicos da Formação Piramboia.

O mapa das unidades aquíferas aflorantes do município de São Gabriel representa as principais unidades hidroestratigráficas (Fig. 4).

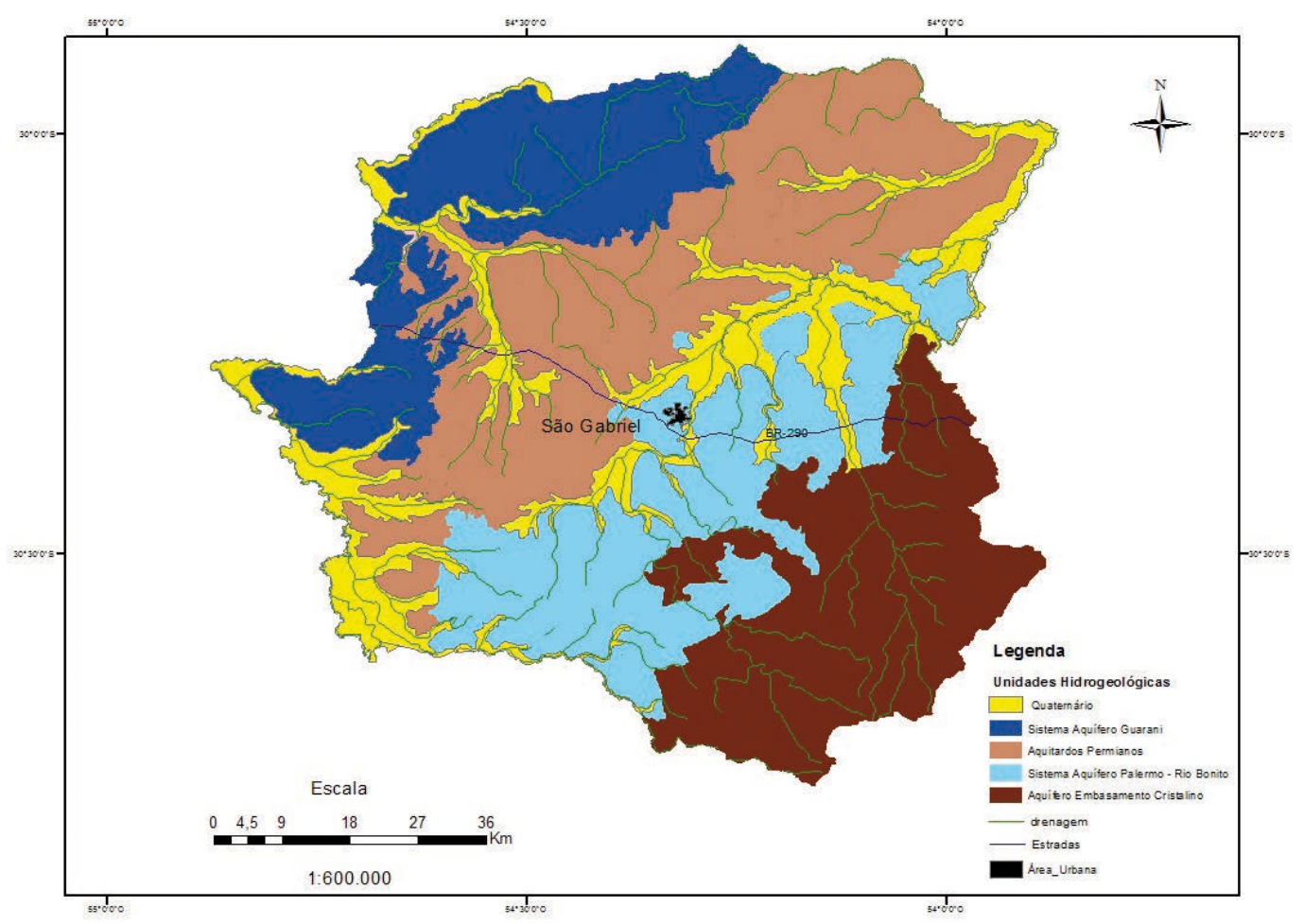

Figura 4. Mapa do município de São Gabriel com as unidades hidrogeológicas aflorantes.

\subsection{Materiais e métodos}

\subsubsection{Levantamento de dados}

Para a realização do estudo foram levantados dados referentes à geologia e hidrogeologia do município de São Gabriel. Os dados hidrogeológicos consistiram no levantamento das informações de 205 poços tubulares cadastrados no banco de dados do Sistema de Informações de Água Subterrânea (SIAGAS-CPRM). Estes dados constam principalmente de perfis geológicos e construtivos de poços tubulares, análises físico-químicas $(\mathrm{pH}$ e condutividade elétrica), coordenadas UTM e informações dos proprietários. Foram levantados ainda, dados de 17 perfis de sondagens para pesquisa de carvão da CPRM (projeto Arco de São Gabriel-Bagé). Para o estudo hidroquímico das águas subterrâneas do município, foram coletadas 55 amostras de água de poços tubulares, escolhidos a partir do SIAGAS e de outros poços tubulares identificados e cadastrados durante as atividades de campo, bem como de poços escavados (representativos de unidade litoestratigráficas) e de sondagens que apresentam surgência. Com base nas informações dos poços cadastrados, foram escolhidos aqueles que apresentavam $\mathrm{pH}$ e condutividade elétrica varia- 
das, representando as principais unidades hidroestratigráficas da região.

\subsubsection{Coleta de amostras e análises}

A coleta das amostras foi realizada em poços que estavam em operação, através de bombeamento, com as próprias motobombas submersas. 0 bombeamento, até a coleta, deu-se por um período não inferior a $15 \mathrm{~min}$, a fim de ser retirada toda a água das tubulações edutoras. Após, as amostras foram acondicionadas em dois frascos, um de 500 $\mathrm{mL}$, preservadas em ácido nítrico para análise de metais e outro de $1 \mathrm{~L}$ para análise dos outros parâmetros. As análises químicas foram executadas pelo laboratório Green Lab - Análises Químicas e Toxicológicas, de Porto Alegre. $\mathrm{O} \mathrm{pH}$, a condutividade elétrica e a temperatura foram medidos in loco em cada poço amostrado, com equipamento pHmetro DM-2P Digimed ( $\mathrm{pH}$ e temperatura) e DM-3P Digimed (condutivímetro).

Os parâmetros analisados em laboratório foram: alcalinidade (bicarbonato, carbonato, oxidrila - métodos titulométricos), Cloro (método do nitrato de mercúrio), Flúor (método colorimétrico SPADNS), nitrato (método do salicilato), sulfato (método turbidimétrico), sulfeto de hidrogênio (método do azul de metileno) e Alumínio, Arsênio, Bário, Cádmio, Cálcio, Chumbo, Cobalto, Cobre, Cromo, Ferro, Magnésio, Manganês, Níquel, Potássio, Selênio e Sódio (método de espectrometria de emissão ótica ICP - EOS).

\subsubsection{Análises estatísticas}

A partir dos resultados analíticos, os dados foram tratados por análises estatísticas multivariada e de agrupamento, a fim de determinar os grupos similares de águas subterrâneas, com base nos íons que apresentaram valores relevantes na análise química e no pH. A análise fatorial foi inicialmente realizada para reduzir o número de parâmetros e então foi feita a análise de agrupamento de amostras de água com afinidade química. Os parâmetros do modelo fatorial foram estimados usando a análise de fatores principais. A análise de agrupamento, por outro lado, foi executada com base nos escores fatoriais com o método da mínima variância Ward e distância Euclidiana ao quadrado sem padronização, utilizando o software SPSS (Statistical Package for Social Science). Os parâmetros químicos utilizados para as análises estatísticas foram: bicarbonato, carbonato, Cloro, Flúor, sulfato, Cálcio, Magnésio, Sódio, Potássio, Ferro ferroso e pH.

\subsubsection{Mapeamento geológico}

0 mapeamento das unidades hidroestratigráficas foi realizado utilizando compilações de mapas geológicos em escala regional existentes, destacando-se daqueles realizados pela CPRM (Wildner, 2005) e o Mapa Geológico na escala 1:250.000 do Grau de São Gabriel (UFRGS, 1972). Análises petrográficas para estudos mineralógicos e texturais de rochas da região estudada, difração de raios X (DRX) para análises de minerais na fração argila, ensaios del/solubilização e ensaios de troca iônica mostraram-se muito importantes para a compreensão dos processos de interação água rocha observados. 0 modelamento hidrogeoquímico, utilizando-se o software EQ3-6, permitiu que fosse estabelecida a especiação dos elementos e as tendências de dissolução e precipitação de minerais na água.

\section{Resultados}

Os resultados analíticos das águas subterrâneas da região de São Gabriel mostram uma grande variedade composicional (Tab. 1). Destacam-se os íons $\mathrm{Ca}^{2+}, \mathrm{Mg}^{2+}, \mathrm{Na}^{+}, \mathrm{SO}_{4}{ }^{2-}, \mathrm{HCO}_{3}{ }^{-}, \mathrm{CO}_{3}{ }^{--}, \mathrm{F}^{-}$e $\mathrm{Cl}$; os parâmetros sólidos totais dissolvidos (STD), condutividade elétrica (CE), alcalinidade e pH como aqueles que possuem significativas variações nas concentrações e determinam diferentes tipos hidroquímicos das unidades hidrogeológicas do município. A análise estatística permitiu separar quatro grupos hidroquímicos distintos utilizando o método Cluster Analisys hierárquico Ward e distância Euclidiana ao quadrado com padronização. Cada grupo possui afinidades hidroquímicas convergentes, representados no dendrograma (Fig. 5), onde se observa que as amostras foram agrupadas no nível de tolerância 5, valor baixo, que estabelece grande similaridade química entre as amostras de um mesmo grupo.

0 mapa dos grupos hidroquímicos (Fig. 6) apresenta as amostras analisadas nos diferentes grupos hidroquímicos da região, inseridos dentro das unidades hidrogeológicas correspondentes.

0 grupo 1 engloba os sistemas aquíferos Embasamento Cristalino (EC), Palermo - Rio Bonito (SAPRB) e Sanga do Cabral-Piramboia (SP), representativo do SAG na região. Estes sistemas aquíferos ocorrem na porção Sul-Sudeste, Noroeste e Leste de São Gabriel e no Oeste do município de Santa Margarida. As águas deste grupo possuem pH entre 6,70 e 8,0, CE entre 42 e $285 \mu \mathrm{S} / \mathrm{cm}$, sendo que todas as amostras são classificadas como águas doces (Fig. 7) e atendem aos padrões de po- 
Tabela 1. Valores médios, máximos e mínimos das concentrações dos principais íons dissolvidos nas águas subterrâneas de São Gabriel, com base em análises feitas em 59 amostras.

\begin{tabular}{lcccccccccc}
\hline & $\begin{array}{c}\mathbf{C E} \boldsymbol{\mu S} / \\
\mathbf{c m}\end{array}$ & $\begin{array}{c}\mathrm{TDS} \\
\mathbf{m g} / \mathbf{L}\end{array}$ & $\begin{array}{c}\mathbf{H C O}_{\mathbf{3}}^{-} \\
\mathbf{m g} / \mathbf{L}\end{array}$ & $\begin{array}{c}\mathbf{C a}^{2+} \\
\mathbf{m g} / \mathbf{L}\end{array}$ & $\begin{array}{c}\mathrm{Cl}^{-} \\
\mathbf{m g} / \mathbf{L}\end{array}$ & $\begin{array}{c}\mathbf{F}^{-} \\
\mathbf{m g} / \mathbf{L}\end{array}$ & $\begin{array}{c}\mathbf{M n}^{2+} \\
\mathbf{m g} / \mathbf{L}\end{array}$ & $\begin{array}{c}\mathbf{K}^{+} \\
\mathbf{m g} / \mathbf{L}\end{array}$ & $\begin{array}{c}\mathbf{N a}^{+} \\
\mathbf{m g} / \mathbf{L}\end{array}$ & $\begin{array}{c}\mathbf{S O}_{\mathbf{4}}^{2-} \\
\mathbf{m g} / \mathbf{L}\end{array}$ \\
\hline Média & 847,0 & 564,0 & 263,0 & 35,0 & 41,0 & 1,3 & 8,0 & 2,6 & 130,0 & 112,0 \\
Máx. & 3740,0 & 2404,0 & 521,0 & 334,0 & 219,0 & 11,6 & 65,0 & 17,0 & 522,0 & 1100,0 \\
Mín. & 42,3 & 26,0 & 9,9 & 1,6 & 5,0 & $\mathrm{ND}$ & 0,1 & 0,1 & 1,2 & 4,0 \\
\hline
\end{tabular}

tabilidade recomendados pela Portaria 518/2004 do MS, CONAMA (2008) e WHO (2002). Uma exceção é observada no poço IO-748 que apresenta concentração de Flúor igual a $1,78 \mathrm{mg} / \mathrm{L}$, que é superior ao limite máximo permitido para consumo humano $(1,5 \mathrm{mg} / \mathrm{L})$. Os poços situados na parte leste do município captam água do ARB. Este fato é corroborado pelas sondagens SG 05, SG 06 e SG 08 (Szubert \& Toniolo, 1981), situadas próximas aos poços amostrados e inseridos neste grupo. As sondagens invariavelmente atravessam arenitos finos a médios e grossos (basais) da Formação Rio Bonito. As espessuras desta unidade variam de 60 a 80 $\mathrm{m}$. Todas as sondagens atingiram o embasamento cristalino.

As águas deste grupo são classificadas, segundo o diagrama de Piper (1944), como bicarbonatadas mistas, sódicas e sulfatadas mistas, sendo que no ARB predominam as águas do primeiro tipo enquanto no SASP predominam as do segundo (Fig. 8). Os poços perfurados nestas unidades possuem profundidades não superiores a $100 \mathrm{~m}$ e as entradas de água normalmente ocorrem em profundidades entre 40 a $60 \mathrm{~m}$. Estes tipos hidroquímicos caracterizam-se por apresentar águas de circulação rápida, próximo às zonas de recarga, além de ocorrer em sistemas de fraturas que interceptam tanto as unidades gonduânicas quanto as do embasamento cristalino.

Os mesmos tipos químicos de águas subterrâneas, bicarbonatadas mistas, sódicas e sulfatadas mistas, foram registrados na região de Candiota-RS, também inserida no Sistema Aquífero Rio Bonito, por Roisenberg et al. (2008) e nas áreas de assentamento da Reforma Agrária na região sul do município de São Gabriel por Goffermann et al. (2012).

As águas do grupo 2 apresentam $\mathrm{pH}$ entre 7,3 e 9,1, CE variando entre 335 e $1451 \mu \mathrm{S} / \mathrm{cm}$; STD entre 237, 31 e $936 \mathrm{mg} / \mathrm{L} ; \mathrm{Na}^{+}$de 39 a $204 \mathrm{mg} / \mathrm{L}$; $\mathrm{SO}_{4}^{-2}$ entre 8,18 e $189 \mathrm{mg} / \mathrm{L} \mathrm{HCO}_{3}^{-2}$ de 275 a 545,34 $\mathrm{mg} / \mathrm{L}$, caracterizando este tipo hidroquímico como águas bicarbonatadas cálcicas, mistas e sódicas (Fig. 9), diferenciando-se do grupo 1 em função da ausência de águas sulfatadas e presença de águas cálcicas. Quanto à salinidade, 31\% das amostras deste grupo são compostas por águas salobras e $69 \%$ por águas doces (Fig. 7).

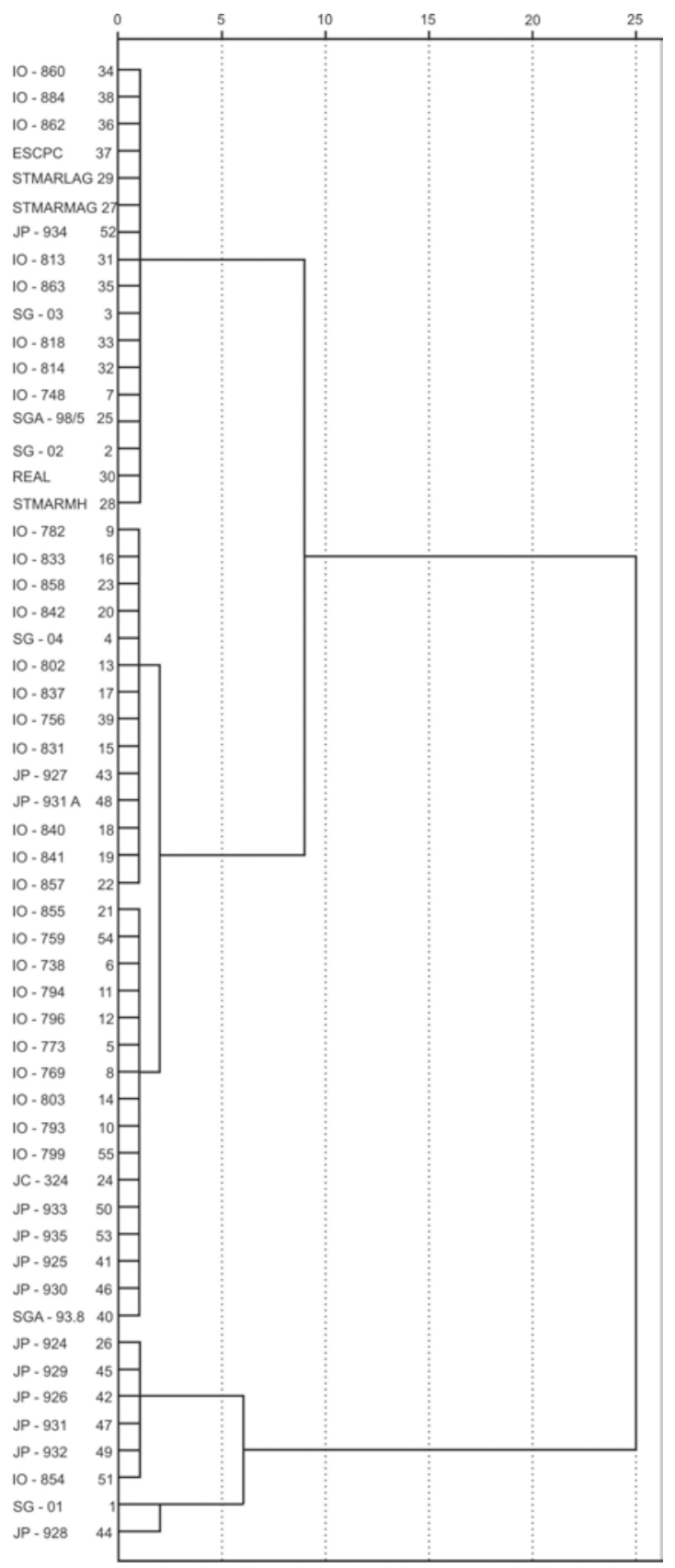

Figura 5. Dendrograma: identificação dos grupos hidroquímicos das águas subterrâneas da região de SG. 0 eixo X contém as distâncias de combinação dos grupos, sendo 5 a distância de corte. A amostra SG-01 não faz parte de nenhum dos grupos. 


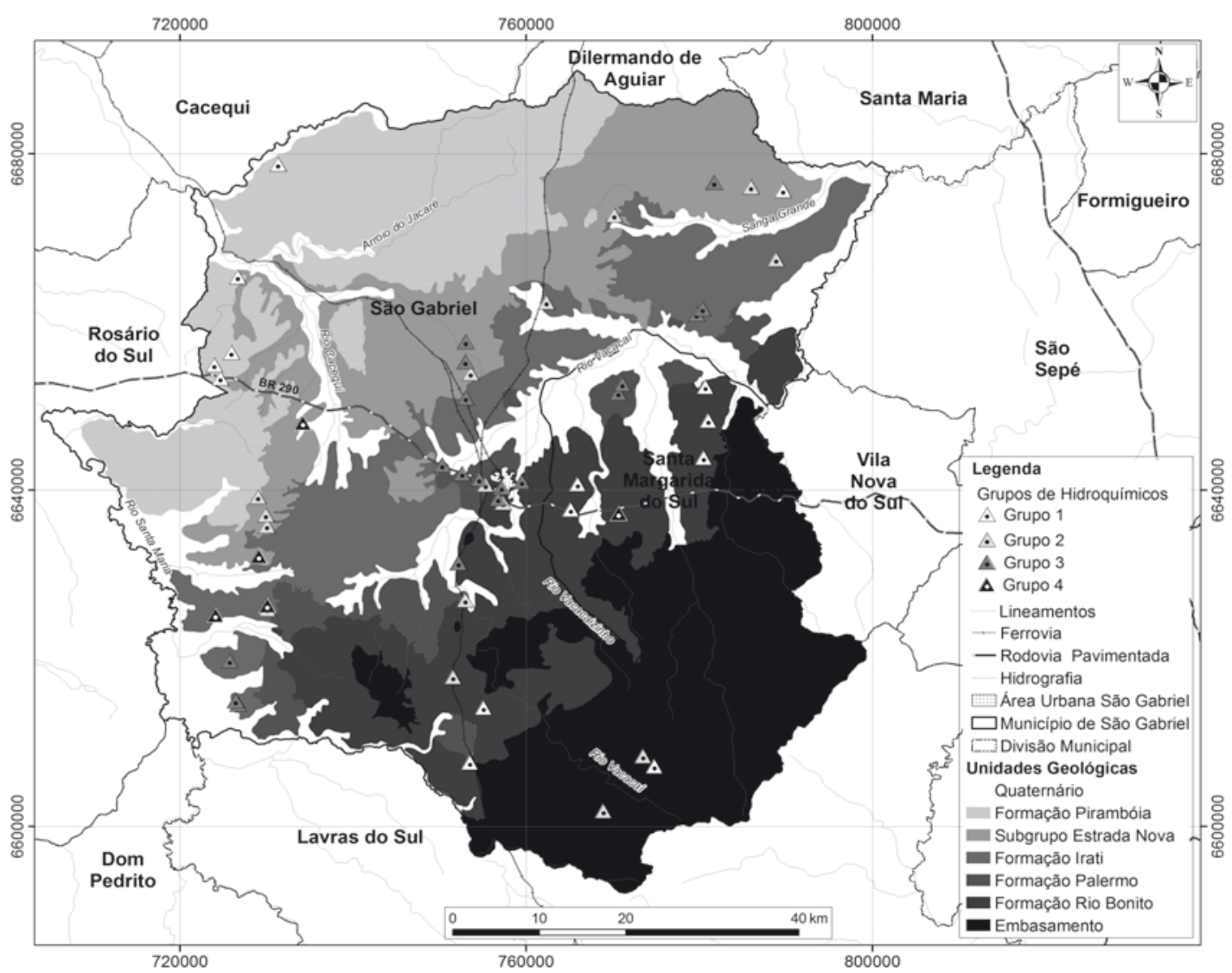

Figura 6. Mapa de distribuição dos grupos hidroquímicos.

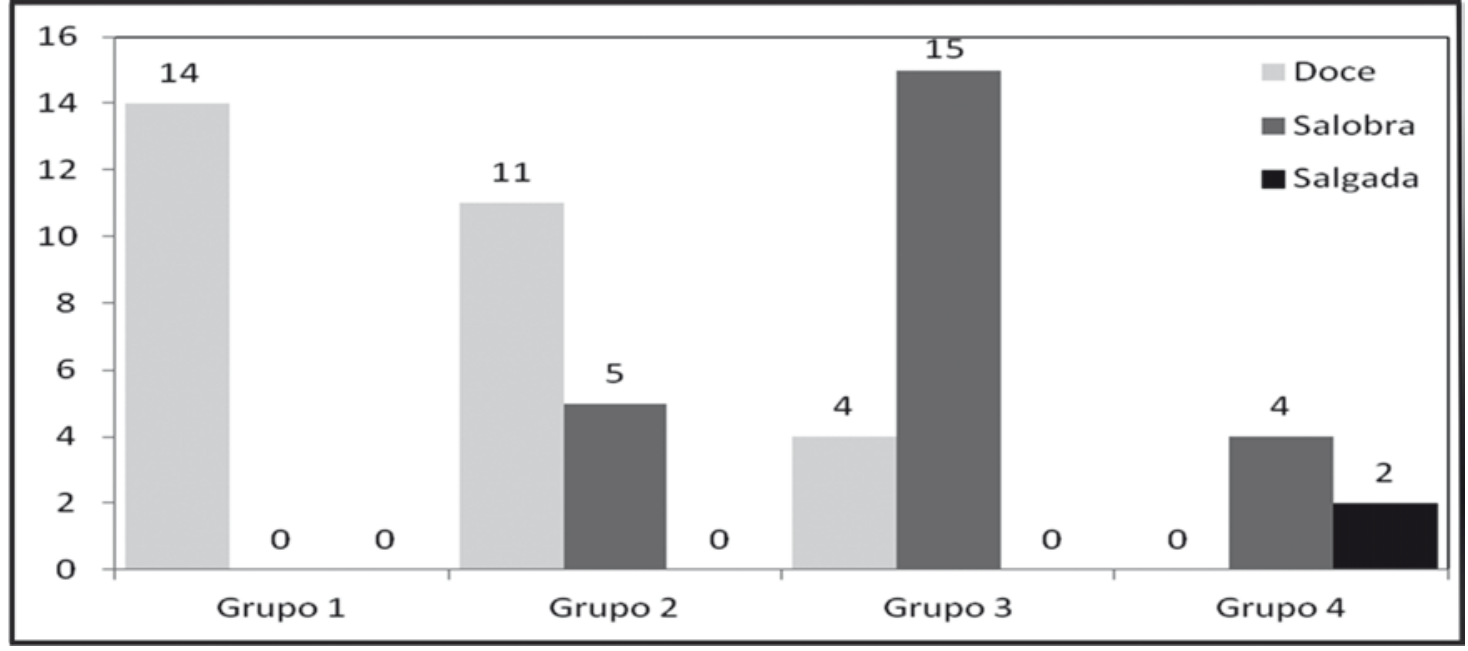

Figura 7. Classificação das águas subterrâneas em relação ao grau de salinização.

Os poços que apresentam águas deste grupo estão instalados em áreas de ocorrência do ARB e dos AP (unidades litoestratigráficas da Formação Irati) . Secundariamente, duas amostras relacionam-se com as unidades do Embasamento Cristalino III. Os poços que captam água exclusivamente do ARB diferenciam-se do grupo 1 pelo aumento considerável na concentração de bicarbonatos, possuindo um comportamento hidroquímico muito semelhante. Este aquífero pode sofrer estas variações principalmente em função das diferenças de composição mineralógica dos cimentos carbonáticos que compõem os arenitos, promovendo maior ou menor intensidade na dissolução destes minerais. Já as águas relacionadas aos AP demonstram incrementos consideráveis nos teores de sais dissolvidos. Embora sejam consideradas como aquitardos, estas unidades muitas vezes comportam-se como aquíferos, possuindo circulação e armazenamento de água subterrânea entre os planos de interlaminações, planos de fraturas, assim como nos níveis e camadas mais arenosas, além de 


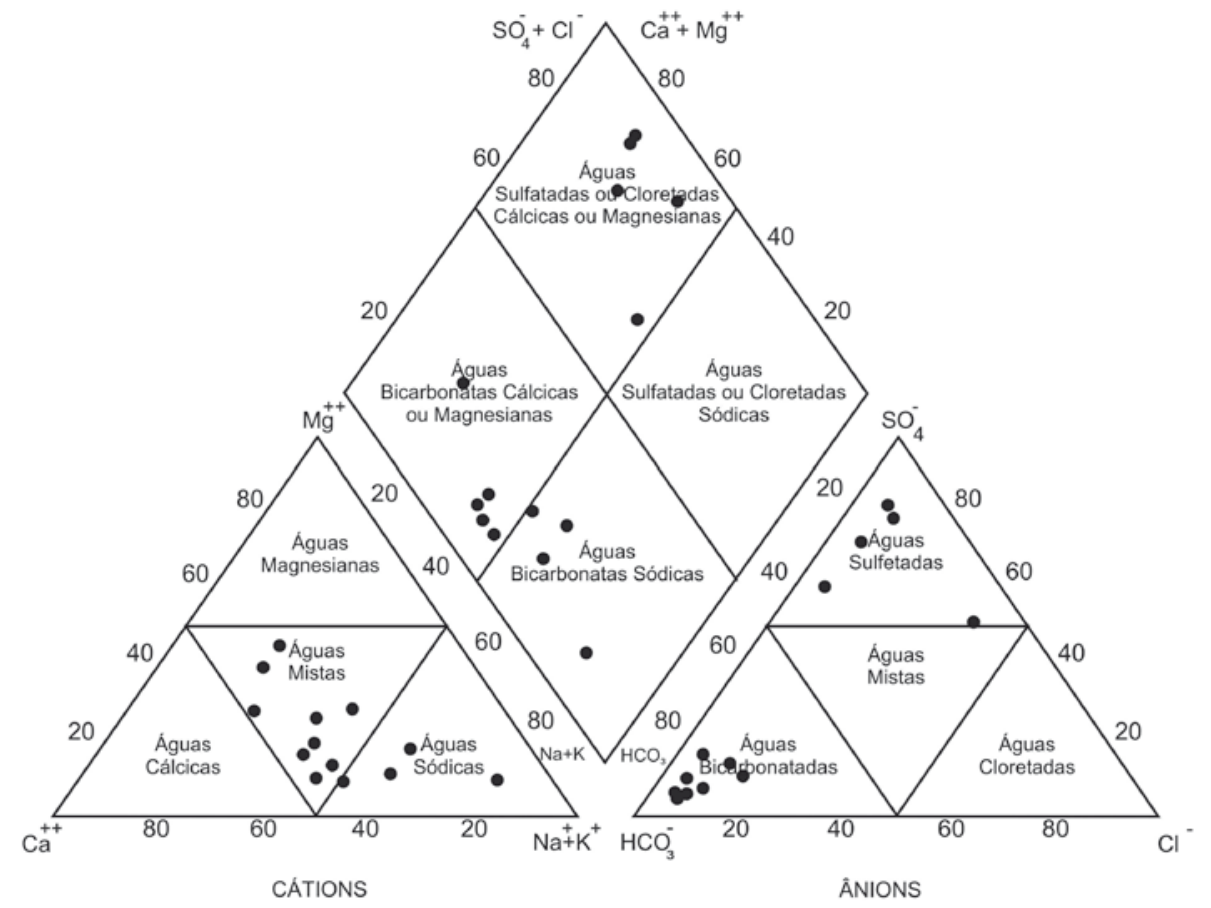

Figura 8. Diagrama de Piper: classificação das águas subterrâneas do grupo 1

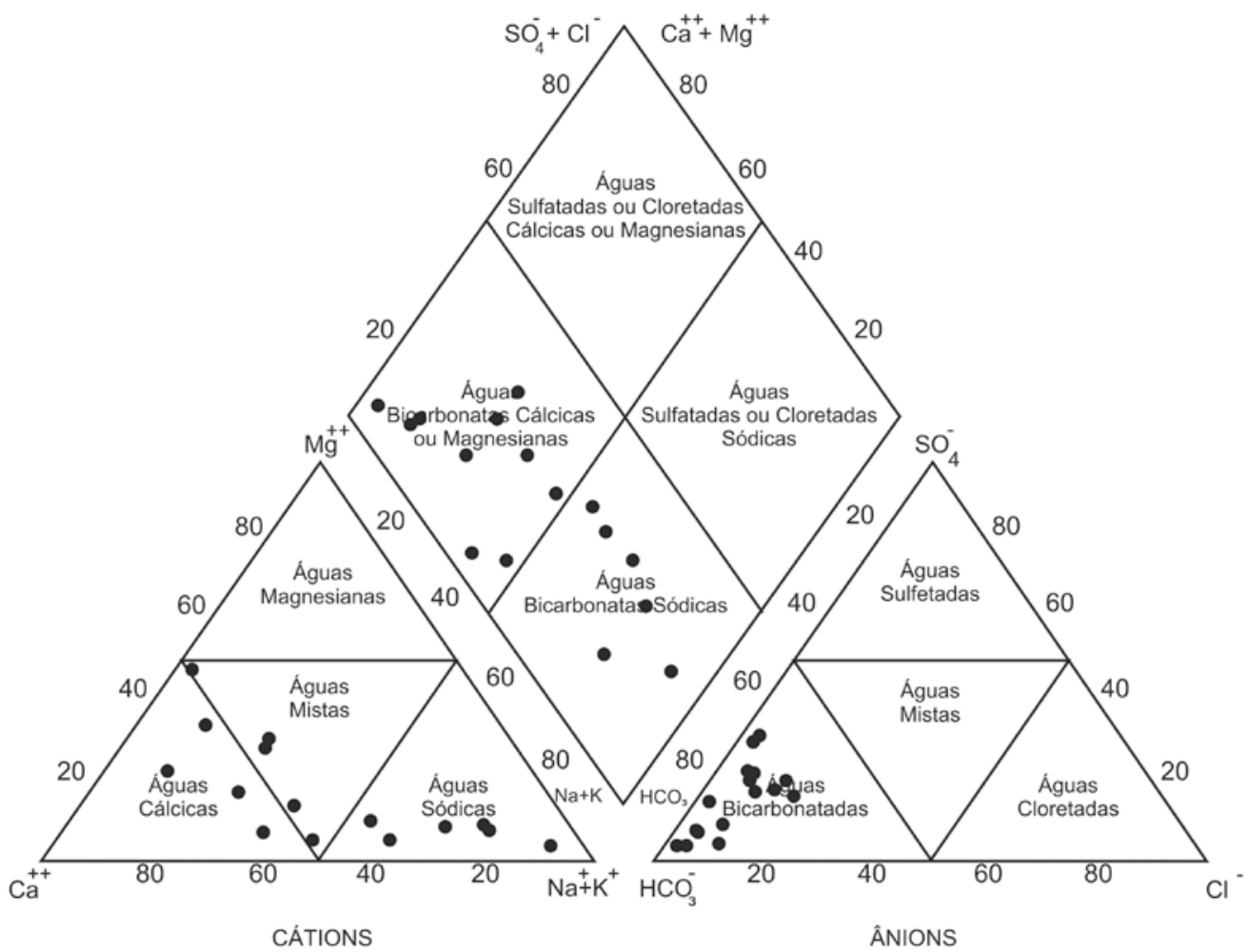

Figura 9. Diagrama de Piper: classificação das águas do grupo 2. 
camadas calcárias.

0 grupo 3 se caracteriza por apresentar águas de má qualidade e juntamente com o grupo 4 correspondem aos tipos hidroquímicos com restrições de potabilidade e outros usos, principalmente devido aos altos teores de $\mathrm{Na}^{+}$e F- São águas alcalinas (pH variando entre 7,89 e 9,20); salinizadas (CE de 586 a $1730 \mu \mathrm{S} / \mathrm{cm}$; STD entre 476,99 e $1112 \mathrm{mg} / \mathrm{L} \mathrm{Na}^{+}$variando de 148 a 296 $\mathrm{mg} / \mathrm{L}$ ), sendo que das 19 amostras deste grupo, 11 possuem teores de $\mathrm{Na}^{+}$acima do limite máximo permitido (200 mg/L). Do total das amostras deste grupo, $98,9 \%$ são consideradas como águas salobras e 21,1\% são doces (Fig. 9). Outro elemento que veda o uso das águas subterrâneas para consumo humano nos locais inseridos neste grupo é o F. Sua concentração varia de 0,10 a 11,60 mg/L, sendo que das 19 amostras, 10 apresentam concentrações acima dos valores máximos de potabilidade $(1,5 \mathrm{mg} / \mathrm{L})$. A classificação deste tipo hidroquímico, conforme o diagrama de Piper (1944), é predominantemente de bicarbonatadas sódicas. Este grupo está inserido dentro dos SAPRB, AP e EC (Fig. 10). Em relação ao primeiro sistema aquífero, as captações parecem estar vinculadas às zonas mais confinadas dos arenitos da Formação Rio Bonito, evidenciadas por sondagens da CPRM (SG-05, SG-12, SG-14 e SG-16), situadas próximas a alguns poços amostrados deste grupo e que apresentam as maiores espessuras de sedimentos finos da Formação Palermo, confinando os arenitos e tornando as captações mais profundas. Neste grupo, as águas caracterizam-se por apresentar concentrações de Sódio menores que aquelas relacionadas aos AP. A associação deste grupo com as áreas de domínio dos AP vincula-se com os aumentos dos teores de Sódio e subordinadamente de Flúor, estando vinculadas principalmente com os sedimentitos da Formação Irati. Os poços associados com o Embasamento Cristalino apresentam teores elevados de Flúor (poços IO 773 - 11,60 $\mathrm{mg} / \mathrm{L}$, IO 738 - 7,43 mg/L e IO $796-1,41 \mathrm{mg} / \mathrm{L}$ ). As concentrações de Sódio chegam ao máximo em $189 \mathrm{mg} / \mathrm{L}$. A tabela 2 apresenta os poços vinculados com as respectivas unidades aquíferas e os teores de Sódio e Flúor.

0 grupo 4 representa o estágio mais avançado em termos de evolução geoquímica das águas subterrâneas na região estudada. Possui os maiores valores de CE (1476 a $3740 \mu \mathrm{S} / \mathrm{cm}$ ) e STD (942 a $2404 \mathrm{mg} / \mathrm{L}$ ), com pH variando entre 6,90 e 8,10 , $\mathrm{Ca}^{+2}$ entre 65,20 e 79,20 mg/L, $\mathrm{Cl}^{-}$entre 70,40 e $219,00 \mathrm{mg} / \mathrm{L} \mathrm{e} \mathrm{Na}^{+}$entre 240 a $522 \mathrm{mg} / \mathrm{L}$. Em termos de salinidade, $80 \%$ das amostras são de água salobra e $20 \%$ de águas salgadas (Fig. 7). Portanto, são águas impróprias para consumo humano, classificadas como bicarbonatadas sódicas (Fig. 11). Todas as amostras representam águas subterrâneas afetadas quimicamente pelos Aquitardos Permianos, constituídos pelo Subgrupo Estrada Nova e Formação Irati. Neste conjunto hidroquímico as concentrações de Flúor são baixas e as de cloretos elevadas. As captações ocorrem principalmente nos níveis arenosos da Formação Irati, entre os planos interlaminares dos folhelhos e em fraturas que interceptam todo o pacote.

Tabela 2. Relação dos poços do grupo hidroquímico 3 com as unidades aquíferas e as concentrações de Flúor e Sódio (abreviações: AP - Aquitardos Permiano, EC - Embasamento Cristalino, SAPRB - Sistema Aquífero Palermo Rio Bonito).

\begin{tabular}{cccc}
\hline Poço & $\begin{array}{c}\text { Unidade } \\
\text { Aquífera }\end{array}$ & Flúor & Sódio \\
\hline IO - 782 & AP & 0,61 & 225,00 \\
IO - 833 & AP & 6,87 & 274,00 \\
IO - 854 & AP & 1,01 & 296,00 \\
IO - 858 & SAPRB & 0,80 & 170,00 \\
IO - 831 & AP & 2,11 & 209,00 \\
IO - 841 & AP & 1,03 & 200,00 \\
IO - 857 & SAPRB & 6,42 & 258,00 \\
IO - 842 & AP & 0,10 & 257,00 \\
IO - 837 & AP & 2,73 & 210,00 \\
IO - 756 & SAPRB & 0,83 & 180,00 \\
SG - 04 & AP & 3,02 & 232,00 \\
IO - 802 & SAPRB & 7,21 & 222,00 \\
IO - 773 & EC & 11,60 & 189,00 \\
IO - 769 & AP & 3,05 & 201,00 \\
IO - 793 & SAPRB & 0,37 & 190,00 \\
IO - 803 & SAPRB & 2,68 & 188,00 \\
IO - 738 & EC & 7,43 & 150,00 \\
IO - 794 & SAPRB & 0,87 & 148,00 \\
\hline & EC & 1,41 & 175,00 \\
\hline
\end{tabular}

Além de ser um tipo hidroquímico inadequado para o consumo humano, as águas do grupo 4 também não são favoráveis para fins de irrigação, conforme demonstra o diagrama SAR (Fig. 12). Este diagrama conhecido como razão de adsorção de Sódio (SAR), é utilizado para a classificação da água com fins de irrigação, demonstrando se a 


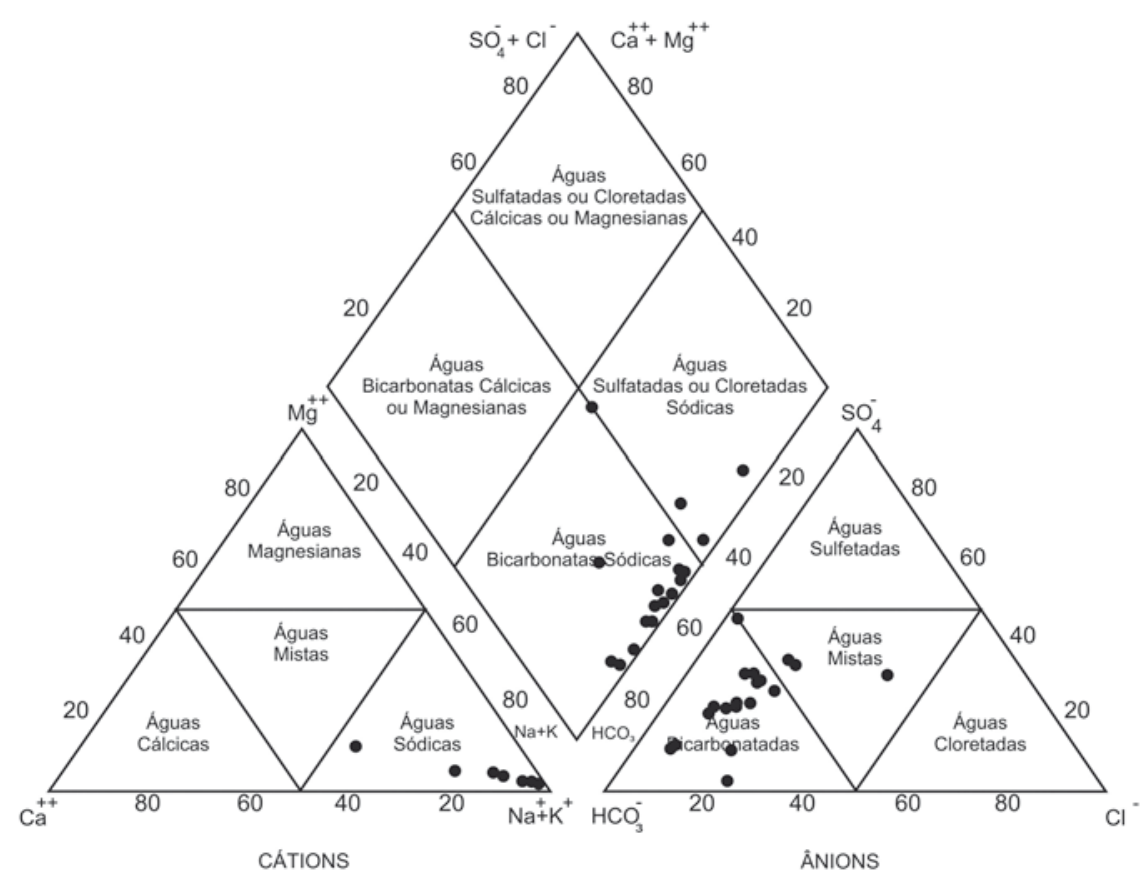

Figura 10. Diagrama de Piper: classificação das águas do grupo 3.

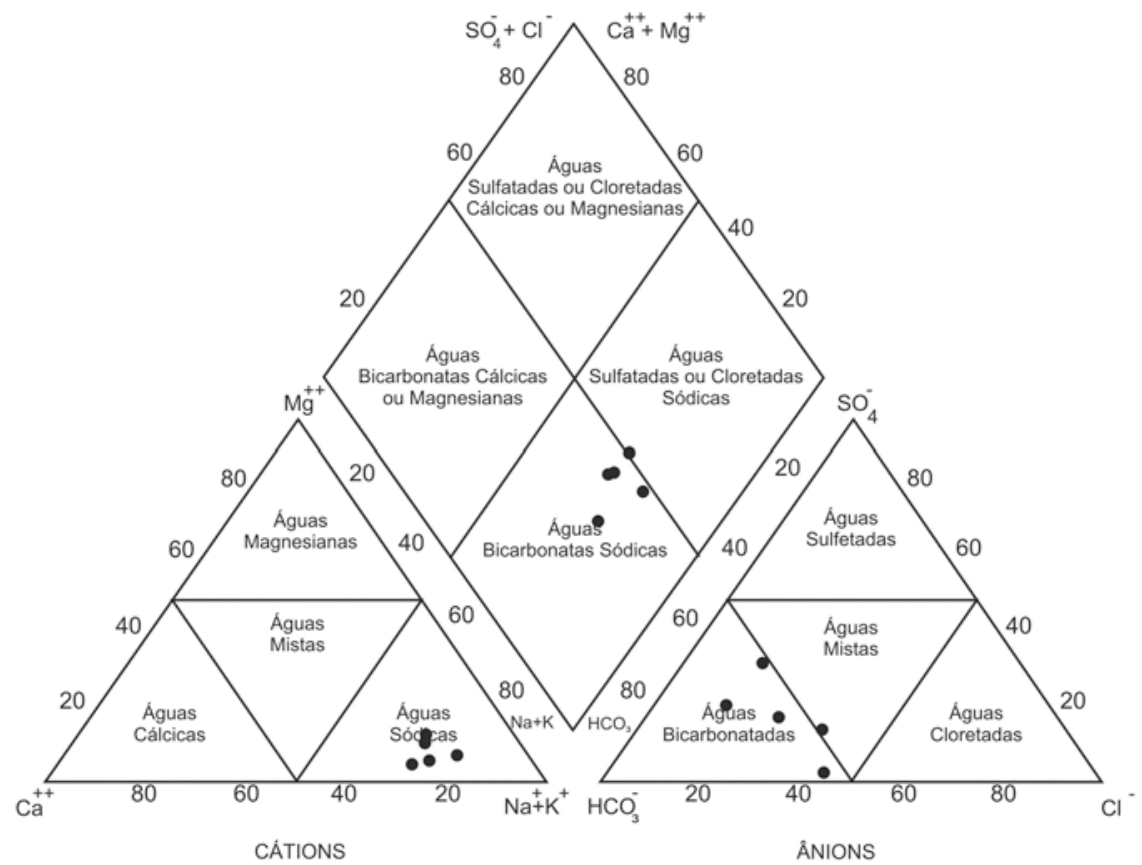

Figura 11. Diagrama de Piper: classificação das águas do grupo 4.

água é apropriada ou não para tal . Quanto maior a SAR, menos apropriada ela será para irrigação. A SAR é uma razão que indica a percentagem de Sódio contido numa água que pode ser adsorvida pelo solo e é calculada através da seguinte equação 1:
(1)

$$
S A R=\frac{N a}{\sqrt{\frac{C a+M g}{2}}}
$$




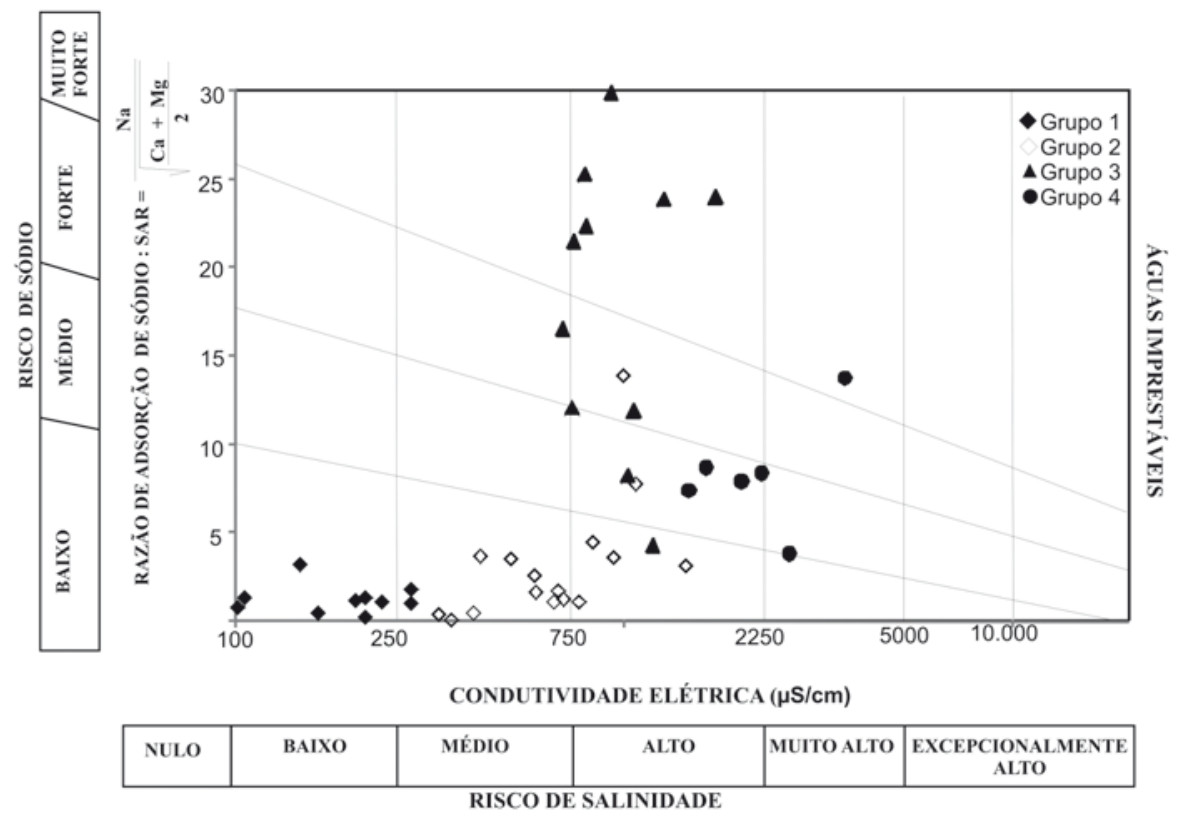

Figura 12. Diagrama SAR x CE: Risco de Salinização e de Sódio para irrigação.

As águas do grupo 4 são consideradas imprestáveis e as do grupo 3 possuem risco de salinidade alto a muito alto para irrigação. Em função das grandes concentrações de Sódio encontradas, principalmente nos grupos hidroquímicos 3 e 4, foram realizados ensaios de troca de cátions para verificar a potencialidade de troca de Cálcio em solução pelo Sódio adsorvido nos minerais e matéria orgânica dos aquíferos, o que poderia levar ao enriquecimento do Sódio dissolvido nas águas subterrâneas. Esta reação de troca tem como resultado águas com elevado conteúdo de Sódio dissolvido sem a correspondente presença de cloretos, como seria esperado pela dissolução de halita, principal fonte de Sódio em águas ricas deste elemento.

Estes ensaios foram realizados em duas etapas. A primeira compreendeu a imersão de amostras desagregadas dos sedimentitos da região em solução de $\mathrm{NaCl}$ 1,0M para que ocorresse a adsorção de Sódio e dessorção do Cálcio adsorvido nos minerais e na matéria orgânica presentes nos aquíferos. Os resultados mostraram a retenção de Sódio e liberação de Cálcio em todas as amostras utilizadas, com exceção do arenito fino do Subgrupo Estrada Nova, onde não houve adsorção do Sódio (Tab. 3).

Tabela 3. Ensaio de troca iônica com $\mathrm{NaCl}$, com íons em mg/L.

\begin{tabular}{|c|c|c|c|c|c|c|c|}
\hline \multirow{2}{*}{ Amostra } & \multirow{2}{*}{ Litologia } & \multirow{2}{*}{$\begin{array}{c}\text { Unidade } \\
\text { litoestratigráfica }\end{array}$} & \multicolumn{3}{|c|}{$\begin{array}{c}\text { Cátions } \\
\text { dessorvidos }\end{array}$} & \multirow{2}{*}{$\begin{array}{c}\text { Na+ } \\
\text { em } \\
\text { solução }\end{array}$} & \multirow{2}{*}{$\begin{array}{l}\mathrm{Na}^{+} \\
\text {adsorvido }\end{array}$} \\
\hline & & & $\mathrm{Ca}^{+2}$ & $\mathrm{Mg}^{+2}$ & $\mathbf{K}^{+}$ & & \\
\hline SG-01B & Argilito cinza & Rio Bonito & 31,9 & 43,8 & 34,9 & 22686 & 45 \\
\hline SG-06A & Folhelho alaranjado & Rio Bonito & 219 & 74,7 & 30,8 & 22172 & 559 \\
\hline SG-12A & Argilito cinza & Irati & 194 & 74,6 & 38,6 & 21305 & 1426 \\
\hline$S G-14 A$ & Folhelho cinza escuro & Irati & 215 & 30,7 & 35,5 & 22673 & 58 \\
\hline$S G-16 A$ & $\begin{array}{c}\text { Folhelho cinza } \\
\text { esverdeado }\end{array}$ & Irati & 692 & 52,1 & 36,6 & 21123 & 1608 \\
\hline SG-16B & Folhelho betuminoso & Irati & 49,9 & 7,18 & 25,6 & 22127 & 604 \\
\hline SG-18A & $\begin{array}{l}\text { Arenito fino } \\
\text { avermelhado }\end{array}$ & Estrada Nova & 318 & 13 & 39,1 & 24636 & -1905 \\
\hline Branco $\mathrm{NaCl}$ & & & 4,3 & 1,02 & 31,30 & 22731 & \\
\hline
\end{tabular}

Na segunda etapa, as amostras de sedimentitos saturadas em Sódio, obtidas na etapa anterior, foram imersas em solução de $\mathrm{CaCl}_{2}$ 0,5M para medir a intensidade de troca de Cálcio dissolvido pelo Sódio adsorvido nos sedimentos. Os resultados ob- tidos indicam intensa troca de Cálcio pelo Sódio, marcada pela grande adsorção do primeiro e solubilização do segundo, com exceção do argilito cinza que não adsorveu Cálcio (Tab. 4). Este processo de troca de cátions produziu soluções com mais 
de $4.000 \mathrm{mg} / \mathrm{L}$ de Sódio, o que pode explicar, em cloreto verificado nas análises. parte, as elevadas concentrações de Sódio e baixo

Tabela 4. Ensaio de troca iônica com $\mathrm{CaCl}_{2}$, com íons em mg/L.

\begin{tabular}{|c|c|c|c|c|c|c|c|}
\hline \multirow{2}{*}{ Amostra } & \multirow{2}{*}{ Litologia } & \multirow{2}{*}{$\begin{array}{c}\text { Unidade } \\
\text { litoestratigráfica }\end{array}$} & \multicolumn{3}{|c|}{$\begin{array}{c}\text { Cátions } \\
\text { dessorvidos }\end{array}$} & \multirow{2}{*}{$\begin{array}{c}\mathrm{Ca}^{+2} \\
\text { em } \\
\text { solução }\end{array}$} & \multirow{2}{*}{$\begin{array}{c}\mathrm{Ca}^{+2} \\
\text { adsorvide }\end{array}$} \\
\hline & & & $\mathbf{M g}^{+2}$ & $\mathbf{K}^{+}$ & $\mathrm{Na}^{+}$ & & \\
\hline SG-01B & Argilito cinza & Rio Bonito & 0,96 & 12,5 & 3231 & 18764 & -404 \\
\hline SG-06A & $\begin{array}{l}\text { Folhelho } \\
\text { alaranjado }\end{array}$ & Rio Bonito & 13,2 & 13 & 2882 & 16134 & 2226 \\
\hline$S G-12 A$ & Argilito cinza & Irati & 14,4 & 16,2 & 3627 & 17008 & 1352 \\
\hline$S G-14 A$ & $\begin{array}{l}\text { Folhelho cinza } \\
\text { escuro }\end{array}$ & Irati & 7,02 & 9,47 & 4061 & 17220 & 1140 \\
\hline$S G-16 A$ & $\begin{array}{l}\text { Folhelho cinza } \\
\text { esverdeado }\end{array}$ & Irati & 12,1 & 11,4 & 4047 & 15370 & 2990 \\
\hline SG-16B & $\begin{array}{c}\text { Folhelho } \\
\text { betuminoso }\end{array}$ & Irati & 2,51 & 12,1 & 3126 & 15709 & 2651 \\
\hline SG-18A & $\begin{array}{l}\text { Arenito fino } \\
\text { avermelhado }\end{array}$ & Estrada Nova & 2,96 & 8,83 & 2465 & 16101 & 2259 \\
\hline Branco $\mathrm{CaCl}_{2}$ & & & 0,19 & 0,21 & 4,67 & 18360 & \\
\hline
\end{tabular}

\section{Discussão}

As águas subterrâneas da região de São Gabriel apresentam comportamento geoquímico bastante variado, tendo sido possível estabelecer, por métodos estatísticos, quatro grupos distintos. Os íons que apresentam valores de concentração mais destacados são os cátions $\mathrm{Na}^{+}$e $\mathrm{Ca}^{2+}$ e os ânions $\mathrm{Cl}^{+}$, $\mathrm{HCO}_{3}{ }_{3}, \mathrm{SO}_{4}{ }^{2-}$ e $\mathrm{F}^{-}$, além dos STD, $\mathrm{pH}$ e condutividade elétrica. Os demais íons dissolvidos e os metais analisados não apresentaram concentrações relevantes. As classificações englobam águas predominantemente bicarbonatadas variando de cálcicas a sódicas, e mistas. Os tipos sulfatados aparecem em menor proporção, associados aos grupos 1 e 3 .

Os conteúdos de $\mathrm{Na}^{+}$e F- e STD são os parâmetros que indicaram problemas de potabilidade destas águas, sendo que do total das 55 amostras analisadas, $30 \%$ apresentam-se impróprias para o consumo humano. As águas são impróprias para consumo humano quando apresentam teores de STD, fluoretos e Sódio superiores a $1000 \mathrm{mg} / \mathrm{L}$, $1,5 \mathrm{mg} / \mathrm{L}$ e $200 \mathrm{mg} / \mathrm{L}$, respectivamente. 0 fluoreto aponta, também, para a restrição de uso para dessedentação de animais e irrigação, cujos respectivos limites máximos permitidos correspondem a 2,0 mg/L e 1,0 mg/L, enquanto também é limitado a $300 \mathrm{mg} / \mathrm{L}$ para recreação (CONAMA, 2008).

As concentrações dos íons dissolvidos estão vinculadas diretamente à circulação das águas nas litologias atravessadas, ao tempo de residência e à distância das zonas de recarga. Com base na localização geográfica e hidrogeológica dos quatro tipos hidroquímicos, foi possível estabelecer uma correlação dos principais íons dissolvidos com as unidades litoestratigráficas e com os sistemas aquíferos identificados na área.

\subsection{Sódio}

O Sódio é um elemento relativamente abundante na crosta, onde ocorre em rochas ígneas, sedimentares e metamórficas. Nas rochas ígneas e metamórficas está presente em minerais de baixa solubilidade, como feldspatos, micas, anfibólios e piroxênios, enquanto em rochas sedimentares pode ocorrer em fases minerais de elevada solubilidade, como a halita, presente em evaporitos e outros sedimentos marinhos. Os evaporitos e os sedimentitos de ambientes oceânicos são as rochas que apresentam as maiores concentrações de Sódio em relação aos outros elementos (Hitchon et al., 1999). Em meios aquosos, quando o Sódio está em solução, a tendência é que permaneça neste estado, dado que não há precipitação de minerais de Sódio que faça diminuir seus teores na água, ao contrário, por exemplo, da precipitação de carbonatos que controlam o conteúdo de Cálcio dissolvido. O Sódio, por outro lado, é adsorvido por muitos minerais, principalmente as argilas, que em processos de troca de cátions tendem a reter os divalentes, como o Cálcio e o Magnésio, e liberar os monovalentes, como o Sódio (Hitchon et al., 1999). As águas subterrâneas analisadas na região de São Gabriel apresentam concentrações entre 1,24 a $522,00 \mathrm{mg} / \mathrm{L}$, sendo que $30 \%$ dos poços contêm mais de $200 \mathrm{mg} / \mathrm{L}$, todos, com uma exceção, pertencentes aos grupos hidroquímicos 3 e 4 . 0 grupo 3 registra amostras com teores a partir de 148,00 $\mathrm{mg} / \mathrm{L}$, enquanto no grupo 4 todas têm mais de $240,00 \mathrm{mg} / \mathrm{L}$. Os aquíferos que sofrem influência da Formação Irati e do Subgrupo Estrada Nova são os que apresentam mais Sódio na região estudada, posicionados dentro de uma estruturação tectônica regional NE-SW, que os separa das demais 
unidades. A figura 13 apresenta a distribuição das concentrações de Sódio na região de São Gabriel onde se observa que os valores maiores que 200 $\mathrm{mg} / \mathrm{L}$ ocorrem numa faixa NE-SW coincidente com as áreas aflorantes da Formação Irati.

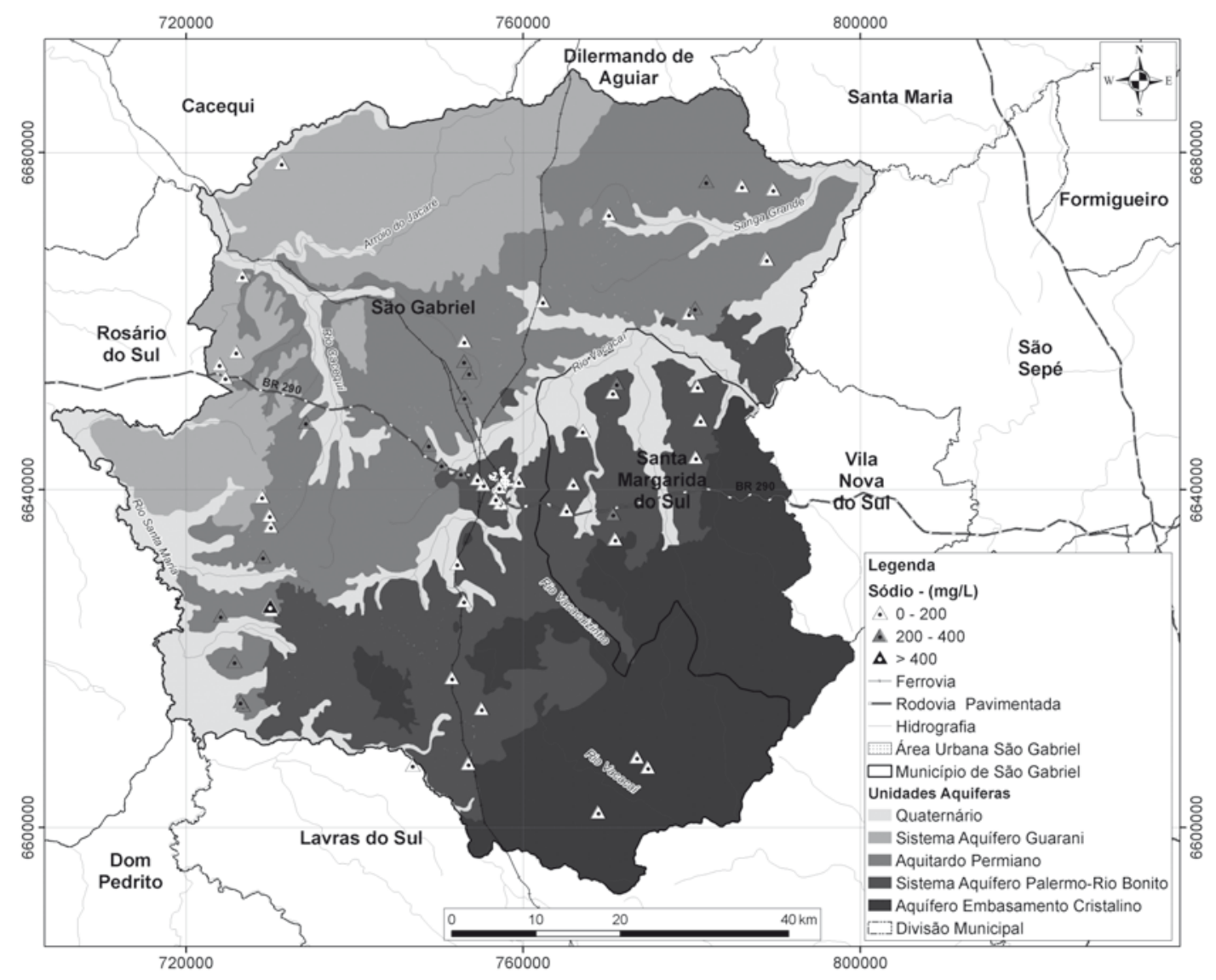

Figura 13. Mapa esquemático com a distribuição das concentrações de $\mathrm{Na}^{+}$na região de São Gabriel.

O elevado conteúdo de Sódio parece estar relacionado a dois processos geoquímicos distintos: i) dissolução de halita e ii) troca de cátions entre as águas subterrâneas e os argilo-minerais presentes nas rochas das unidades Irati e Subgrupo Estrada Nova.

A dissolução de halita é identificada nas concentrações relativamente altas do cloreto nos grupos hidroquímicos 3 e 4, não sendo, contudo, o único processo responsável pela solubilização de Sódio. Grande parte do Sódio presente nas águas subterrâneas da região estudada resulta de processos de troca de cátions, nos quais argilo-minerais do grupo das esmectitas retêm o Cálcio em solução e liberam o Sódio adsorvido (reação 1). As esmectitas ocorrem disseminadas e em camadas centimétricas nos sedimentitos da Formação Irati (Fig. 14). Estes minerais sugerem que as reações de troca ocorrem, o que é também evidenciado pela baixa concentração de Cálcio nestas águas que circulam em ambientes bastante carbonatados, demonstrando que a dissolução de sais de Sódio, especialmente a halita, não é a reação que predo- mina nestes processos geoquímicos. Os sedimentos finos presentes em unidades litoestratigráficas da região, com permeabilidades baixas, propiciam maior tempo de residência destas águas, favorecendo as reações de trocas de cátions.

O Cálcio trocado é oriundo da dissolução e hidrólise de sulfatos e carbonatos, conforme as reações 2 e 3.

$$
\begin{aligned}
& 2 \mathrm{Na}^{+?}{ }_{(\mathrm{ads})}+\mathrm{Ca}^{2+}{ }_{(\mathrm{aq})} \rightarrow \mathrm{Ca}_{(\mathrm{ads})}+2 \mathrm{Na}^{+}{ }_{(\mathrm{aq})} \\
& \mathrm{CaSO}_{4(\mathrm{~s})} \leftrightarrow \mathrm{Ca}^{2+}{ }_{(\mathrm{aq})}+\mathrm{SO}_{4}^{2-}{ }_{(\mathrm{aq})} \\
& \mathrm{CaCO}_{3(\mathrm{~s})}+\mathrm{H}_{2} \mathrm{O} \leftrightarrow \mathrm{Ca}^{2+}{ }_{(\mathrm{aq})}+\mathrm{HCO}_{3(\mathrm{aq})}+(\mathrm{OH})^{-}
\end{aligned}
$$

A solubilização de Sódio pela troca catiônica com Cálcio oriundo da dissolução da anidrita fica evidenciada pela boa correlação das concentrações de sulfato com o somatório das concentrações de Cálcio e Sódio trocado (Fig. 15). O Sódio trocado corresponde à diferença entre a concentração medida na amostra e a concentração equivalente à dissolução da halita, sendo esta determinada a 
partir do cloreto medido na amostra obedecendo halita é de 1:1,5 em mg/L. a relação estequiométrica, conforme reação 4 . A relação estequiométrica do Sódio e o cloreto na $\mathrm{NaCl} \leftrightarrow \mathrm{Na}^{+}+\mathrm{Cl}^{-}$

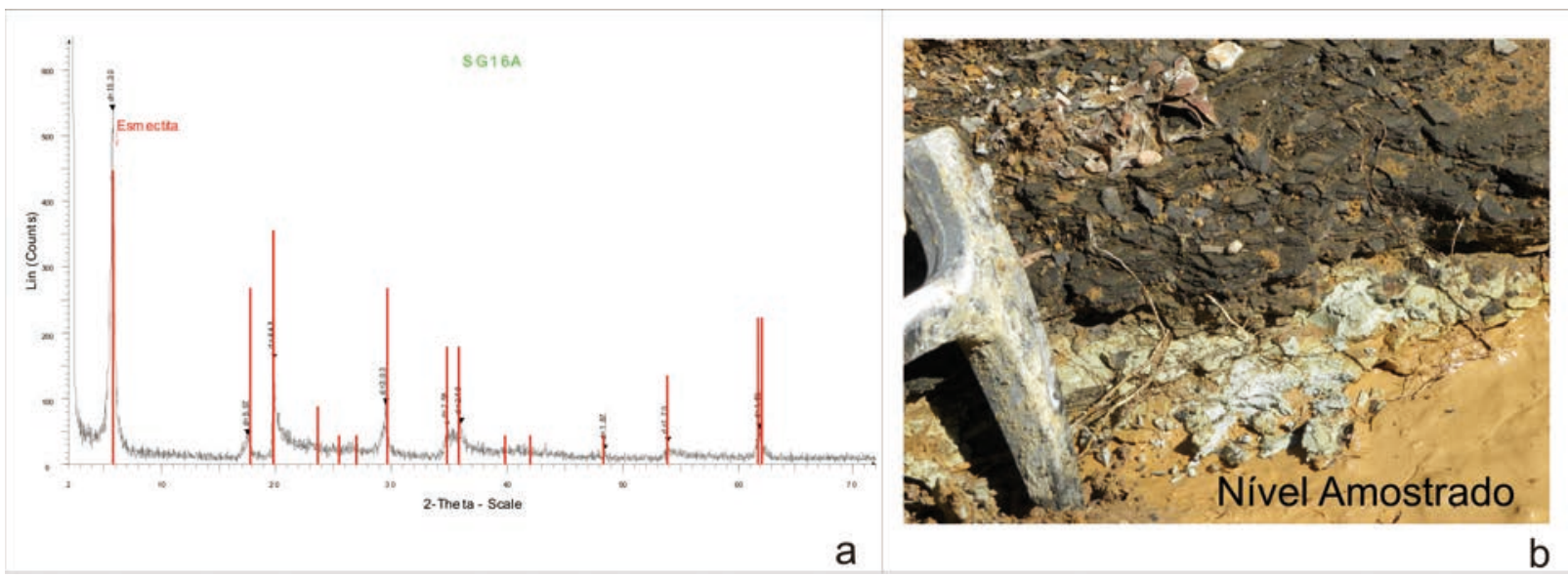

Figura 14. Difratograma de raios-X mostrando a presença de esmectita na camada centimétrica de coloração clara.

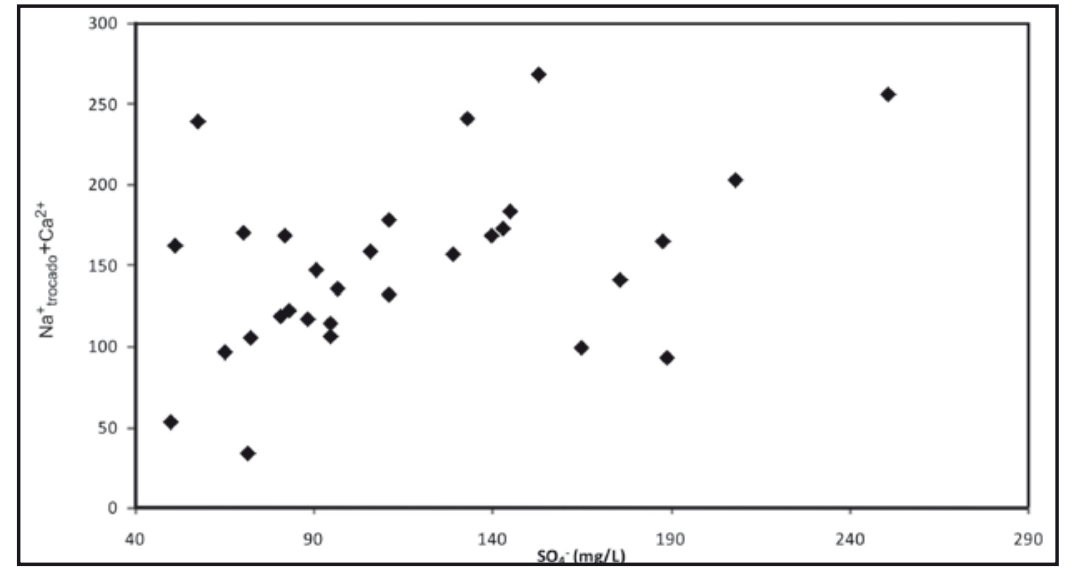

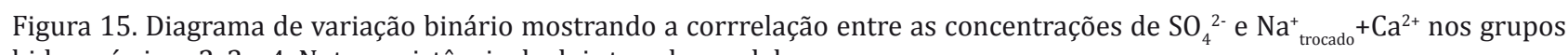
hidroquímicos 2, 3 e 4. Note a existência de dois trends paralelos.

\subsection{Flúor}

O elemento Flúor, na sua forma iônica F- é outro parâmetro que compromete o uso de água subterrânea na área estudada. Conforme a Resolução do CONAMA (2008), Portaria 518 do Ministério da Saúde (2004) e WHO (2012), a concentração máxima de Flúor permitida para consumo humano é de $1,5 \mathrm{mg} / \mathrm{L}$. Ainda segundo CONAMA (2008), para a dessedentação de animais e irrigação, os valores máximos permitidos de Flúor são de 2,0 e 1,0 mg/L, respectivamente. Na região de São Gabriel, $20 \%$ das amostras analisadas registram teores acima de 1,5 mg/L de F- (Fig.16).

A ocorrência de $\mathrm{F}^{-}$em concentrações elevadas nas águas subterrâneas pode ter origem natural ou antrópica, sendo que não há evidências desta última na região estudada. As fontes antrópicas residem, principalmente, na utilização de pesticidas e fertilizantes fosfatados contendo Flúor e pela deposição a partir de emissão de gases e par- tículas provenientes principalmente de fundições de alumínio e das indústrias químicas e cerâmicas. Minerais como apatita e micas contêm Flúor em suas composições, mas a origem natural deste ânion nas águas subterrâneas está principalmente relacionada à dissolução da fluorita (Hem, 1970; Stumm \& Morgan, 1996; Hitchon, 1999), conforme reação 5:

$\mathrm{CaF}_{2(\mathrm{~s})} \leftrightarrow \mathrm{Ca}^{2+}{ }_{(\mathrm{aq})}+2 \mathrm{~F}_{(\mathrm{aq}\}}^{-}$

Para o consumo diário é recomendado o teor de $0,5 \mathrm{mg} / \mathrm{L}$ de fluoreto, tanto na forma de alimentos quanto na ingestão de água. Este consumo é importante para os organismos, principalmente na proteção dos dentes contra cáries (WHO, 2012). Entretanto, a ingestão prolongada de quantidades excessivas de Flúor diariamente pode provocar doenças severas, como as fluoroses dentária e esquelética. A primeira acomete principalmente crianças até 5 anos, afetando o esmalte dos dentes 
em formação, ocasionando uma série de implicações clínicas, tais como manchas, deformidades anatômicas dos dentes, até sua perda completa. A ingestão de águas com teores acima de $0,9 \mathrm{mg} / \mathrm{L}$, adicionadas a outras formas de consumo do Flúor, já pode originar esta enfermidade (WHO, 2012).

A fluorose esqueletal ocorre em adultos, através do uso prolongado de água com teores elevados de Flúor, acarretando deformação nos ossos, dores nas articulações, limitações nos movimentos e diminuição da densidade óssea. Segundo WHO (2012), consumos diários de água com concentrações entre 3-6 mg/L de Flúor já podem gerar esta doença, dependendo dos volumes diários consumidos e a forma de absorção pelos organismos.

Estudos sobre o Flúor e suas origens já foram realizados em aquíferos da Bacia do Paraná, procurando relacioná-las com as unidades litoestra- tigáficas atravessadas pelos poços tubulares e os aquíferos correspondentes (Marimon, et al., 2007; Kern et al., 2008; Nanni et al., 2009). Na porção sul da Bacia, em território gaúcho, os estudos foram realizados nas unidades triássicas e juro-cretáceas, destacando-se os trabalhos de Silvério da Silva et al . (2006), Marimon (2006), Frank et al. (2007), Marimon et al. (2007), Nanni (2008), Ben da Costa et al. (2008) e Santiago \& Silvério da Silva (2009).

A ocorrência de elevado Flúor ( $>1,5 \mathrm{mg} / \mathrm{L}$ ) observada na área de estudo está relacionada, principalmente, aos aquíferos do Embasamento Cristalino (EC), Rio Bonito (RB) e em áreas onde afloram as unidades Subgrupo Estrada Nova (EN), Formações Irati (IR e Palermo (PA ), conforme tabela 4 . Todas as amostras pertencem ao grupo hidroquímico 3, com exceção de uma (IO-748) pertencente ao grupo 1.

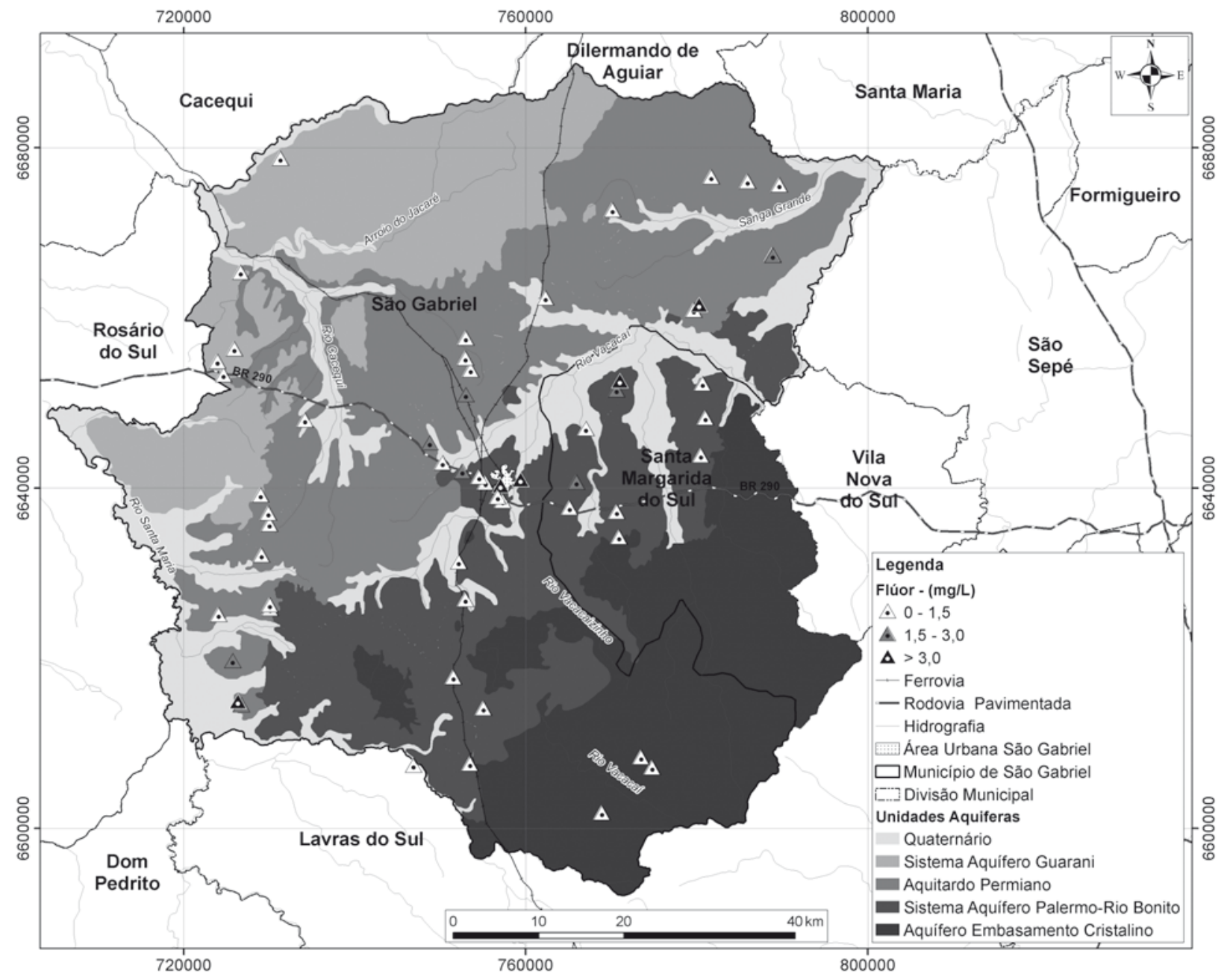

Figura 16. Mapa esquemático com a distribuição das concentrações de F- na região de São Gabriel. 
As altas concentrações de Flúor na área estudada, provavelmente, têm origem relacionada à dissolução de fluorita presente nas fraturas do Embasamento Cristalino e disseminada na Formação Irati, podendo estar vinculada aos seguintes processos hidrogeológicos: i) circulação da água subterrâneas através de sistemas de fraturas no Embasamento Cristalino; ii) circulação da água nas unidades hidroestratigráficas do Subgrupo Estrada Nova e ou Formação Irati; iii) circulação da água nas porções confinadas e profundas do Aquífero Rio Bonito com influência da Formação Irati a partir das estruturas frágeis regionais de direção preferencial NE-SW que estabelecem conexão hidráulica entre as unidades gonduânicas.

Na região de São Gabriel, as rochas graníticas do Embasamento Cristalino afloram somente na extremidade S-SE e nas demais áreas estão cobertas pelas unidades gonduânicas. Dos poços que captam água exclusivamente no Aquífero Embasamento Cristalino, apenas três (IO-733, IO-738 e I0-796) registram concentrações de Flúor maiores que $1,5 \mathrm{mg} / \mathrm{L}$. Nestes locais, o aquífero está confinado pelos sedimentos da Formação Rio Bonito (aquífero Rio Bonito) com espessura de aproximadamente $40 \mathrm{~m}$. Isso sugere que este aquífero contém fluorita preenchendo fraturas (Iglesias, 2000), a qual sofre dissolução enriquecendo a água subterrânea em Flúor. Nas águas captadas neste aquífero em locais não confinados, as concentrações de Flúor são baixas, o que pode também ser decorrente da circulação mais rápida com menor dissolução da fluorita e maior diluição de Flúor nas águas subterrâneas.

Os dados da tabela 4 mostram que o maior número de amostras com teores elevados de Flúor corresponde aos poços localizados nas unidades Subgrupo Estrada Nova e Formação Irati. Embora não sejam consideradas como aquíferas, nestas unidades litoestratigráficas podem circular águas subterrâneas através dos planos de fraturas, níveis e concreções carbonáticas presentes em ambas, planos interlaminares, camadas e lentes arenosas e zonas de alteração de minerais que podem gerar porosidades secundárias.

Kern et al. (2008) estudaram a possível origem de fluoreto no Aquífero Guarani relacionada aos folhelhos betuminosos das formações Irati e Ponta Grossa. Nestas litologias foi registrada a presença de fluorita diagenética microcristalina associada aos níveis com matéria orgânica, além de calcita, dolomita, ankerita, apatita, pirita e barita. Nestes materiais foram realizados ensaios de lixiviação/solubilização que revelaram elevadas concentrações de fluoreto nas soluções geradas. Com isto, aqueles autores concluíram que os microcristais de fluorita nos folhelhos do Irati podem ser solubilizados e grande quantidade de fluoreto lixiviada para as águas subterrâneas, caracterizando o grande potencial desta formação como fonte das altas concentrações de Flúor no Aquífero Guarani no Rio Grande do Sul. A interação das águas subterrâneas dos folhelhos com as águas do Aquífero Guarani ocorre através da circulação por falhas profundas e lineamentos tectônicos que constituem uma conexão hidráulica entre estes dois pacotes sedimentares. Cabe destacar que a Formação Irati aflora ao longo de uma faixa de direção NE-SW com largura da ordem de $15 \mathrm{Km}$ na zona central da área estudada, podendo constituir, portanto, uma fonte do fluoreto registrado com elevadas concentrações nas águas subterrâneas.

\subsection{Cálcio, Magnésio e Potássio}

Os demais cátions que normalmente registram concentrações significativas nas águas subterrâneas, como Cálcio, Magnésio e Potássio, ocorrem em pequenas quantidades nos aquíferos da região de São Gabriel, sendo suas proporções caracterizadas da seguinte forma em todos os grupos hidroquímicos:

$$
\mathrm{rCa}^{2+}>\mathrm{rMg}^{2+}>\mathrm{rK}^{+} \text {, }
$$

onde $\mathbf{r}$ é a razão da concentração de cada elemento pela concentração de sólidos totais dissolvidos (TDS) na amostra.

O Cálcio é um dos elementos mais abundantes das principais rochas ígneas e metamórficas, aparecendo em inúmeros minerais, como feldspatos, piroxênios e anfibólios. Entretanto, as concentrações de Cálcio nas águas subterrâneas em contato com estas rochas e minerais são baixas, principalmente pela lenta taxa de dissolução dos mesmos (Hem, 1985).

Nas rochas sedimentares, as carbonáticas representam as formas mais comuns da presença de Cálcio, constituindo minerais como calcita e aragonita $\left(\mathrm{CaCO}_{3}\right)$ e dolomita $\mathrm{CaMg}\left(\mathrm{CO}_{3}\right)_{2}$, Os sulfatos como anidrita $\left(\mathrm{CaSO}_{4}\right)$ e gipso $\left(\mathrm{CaSO}_{4} \cdot 2 \mathrm{H}_{2} \mathrm{O}\right)$ também são constituintes importantes de Cálcio em sedimentos (Hem, op.cit.).

Nas águas subterrâneas da região estudada, o Cálcio apresenta as concentrações médias mais elevadas no grupo hidroquímico 2, embora no grupo 1 também supere o Sódio (Fig. 17). Já nos grupos hidroquímicos 3 e 4 o Sódio apresenta os teores mais elevados (Fig. 18). 

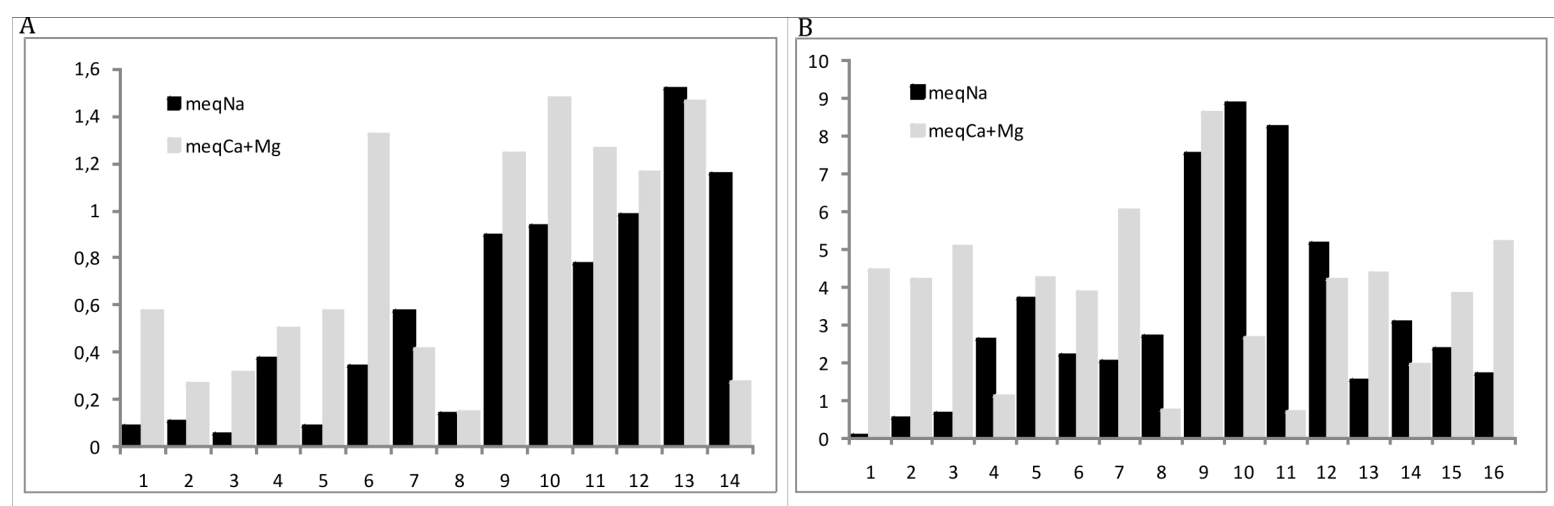

Figura 17. Histograma das concentrações de $\mathrm{Ca}^{2+}+\mathrm{Mg}^{2+}$ e $\mathrm{Na}^{1+}$ no grupo 1 (A) e grupo 2 (B) (em meq/L).
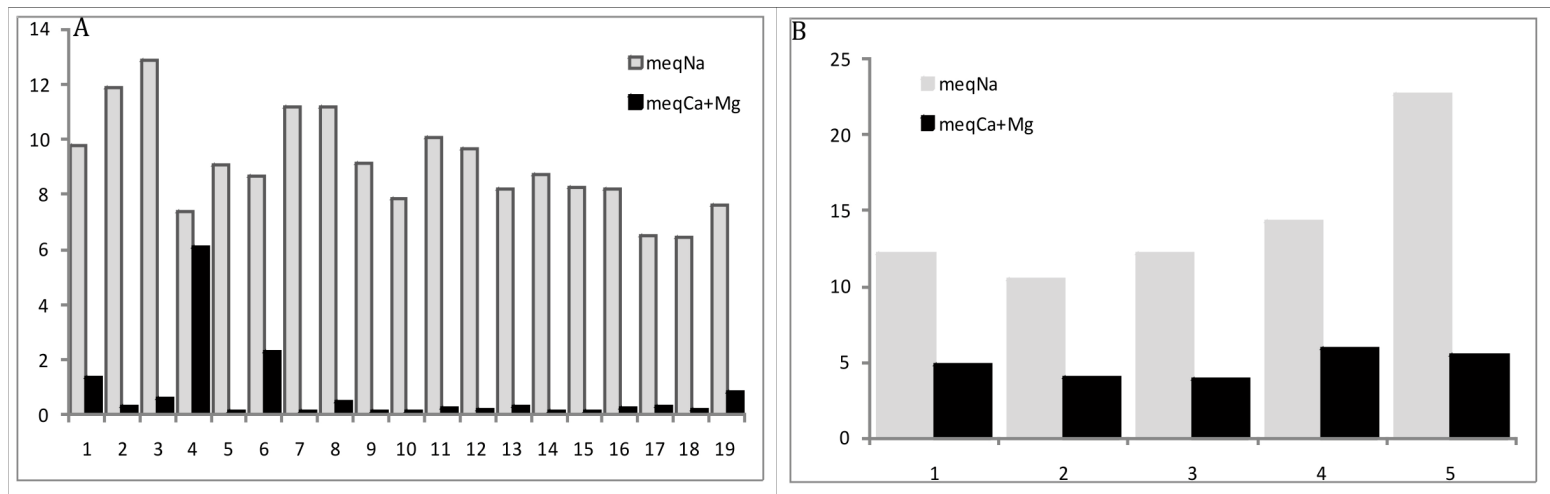

Figura 18. Histograma com as concentrações de $\mathrm{Ca}^{2+}+\mathrm{Mg}^{2+}$ e $\mathrm{Na}^{1+}$ no grupo 3 (A) e grupo 4 (B) (em meq/L).

Conforme mostram as figuras 17 e 18, as concentrações de Cálcio são mais elevadas que as de Sódio nos grupos 1 e 2, onde as águas subterrâneas circulam pelos aquíferos do Embasamento Cristalino e Rio Bonito em sua porção mais próxima das áreas de afloramento. As concentrações de Cálcio são provavelmente oriundas da dissolução de minerais carbonáticos presentes nos cimentos dos arenitos da Formação Rio Bonito. Pelas relações entre o Cálcio e o Magnésio, a calcita é o mineral predominante.

Nas áreas mais afastadas das zonas de recarga (grupos 3 e 4), onde o Aquífero Rio Bonito encontra-se encoberto pelas formações Irati e Estrada Nova, o valor de $\mathrm{rNa}^{+}$é mais elevado do que o valor $\left(\mathrm{rCa}^{2+}+\mathrm{rMg}^{2+}\right)$, sugerindo, mais uma vez, a troca de cátions entre as águas subterrâneas e os argilo-minerais e a matéria orgânica presentes nestas rochas, favorecida pelo maior tempo de residência dentro do aquífero. Desta forma, as baixas concentrações de Cálcio e Magnésio podem ser explicadas pela sua retenção em argilo-minerais.

O Potássio ocorre em pequenas concentrações nas águas subterrâneas da área estudada, variando de 0,13 a 7,93 mg/L. Presente principalmente em feldspatos alcalinos, também faz parte da estrutura de muitos argilo-minerais, provenientes da alteração de rochas graníticas e alcalinas. Devido a sua baixa solubilidade e difícil remoção por hidrólise das estruturas dos argilo-minerais, este cátion é pouco abundante nas águas subterrâneas.

\subsection{Bicarbonatos}

Os bicarbonatos correspondem aos principais ânions presentes nas águas subterrâneas da região de São Gabriel. Suas concentrações variam de 10 a $528 \mathrm{mg} / \mathrm{L}$, com média de $233 \mathrm{mg} / \mathrm{L}$. Todos os grupos hidroquímicos apresentam o bicarbonato como ânion principal, classificando as águas subterrâneas da região. Entretanto, as águas do grupo 1 são as que apresentam menos bicarbonatos, enquanto as dos grupos hidroquímicos 2, 3 e 4 são as mais enriquecidas. A grande abundância de bicarbonatos nas águas subterrâneas da região está relacionada, principalmente, à dissolução de calcita presente na matriz das rochas sedimentares da Bacia do Paraná. No Sistema Aquífero Piramboia-Sanga do Cabral, o bicarbonato tem os menores conteúdos da região, o que é coerente com a mineralogia deste aquífero, composta essencialmente por quartzo e feldspatos. Da mesma forma, há um aumento de bicarbonato no Aquífero Rio Bonito quando este se encontra confinado pelos aquitardos permianos, nos quais os bicarbonatos são muito abundantes. 


\subsection{Sulfatos}

Os sulfatos apresentam concentrações de até $251 \mathrm{mg} / \mathrm{L}$ com valores acima de $200 \mathrm{mg} / \mathrm{L}$ nos grupos 2, 3 e 4, nos quais apenas uma amostra ultrapassa o limite de potabilidade estabelecido pelo Ministério da Saúde, que corresponde a 250. A distribuição das concentrações do sulfato na área estudada é apresentada na figura 19.

0 grupo 1, que contêm poços do Embasamento Cristalino, das formações Rio Bonito e Piram- bóia , registra os teores mais baixos, predominando aqueles menores que $50 \mathrm{mg} / \mathrm{L}$ (Fig. 20). Cabe destacar que as águas subterrâneas que apresentam as maiores concentrações dentro do Grupo 1 são relacionadas à Formação Pirambóia, onde o sulfato varia de 79 a $96 \mathrm{mg} / \mathrm{L}$, o que se deve, provavelmente, a ocorrência de anidrita cristalizada em ambiente árido a semiárido, característico da deposição das fácies eólicas desta formação (Gastmans, 2007).

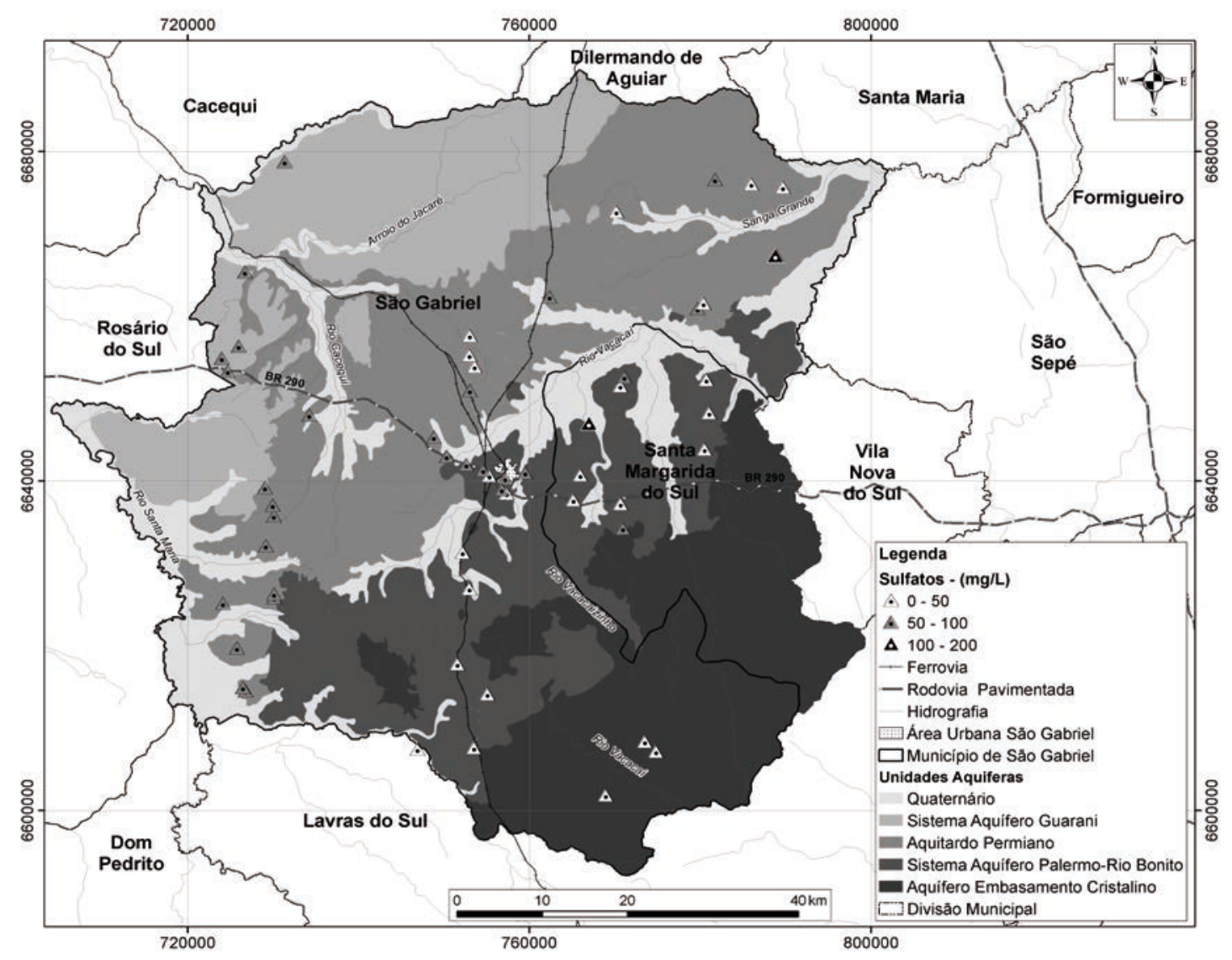

Figura 19. Distribuição da concentração de $\mathrm{SO}_{4}{ }^{-}$nas águas subterrâneas da região de São Gabriel.

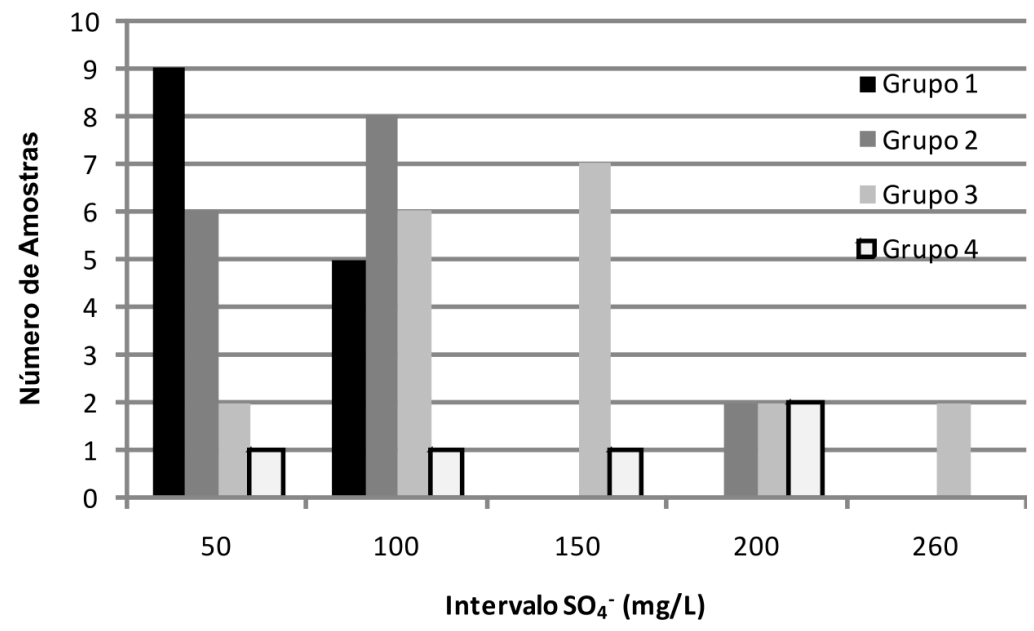

Figura 20. Histograma de frequência das concentrações de sulfato nas águas subterrâneas separadas por grupo hidroquímico. 


\section{Conclusões}

0 presente estudo permitiu identificar o Aquífero Rio Bonito (ARB) e o Sistema Aquífero Sanga do Cabral-Pirambóia como os melhores da região de São Gabriel em termos de qualidade e volume explotável. O ARB apresenta sua melhor situação nas áreas em que ele está aflorante, região Sul- Sudeste do município. Nesta situação, as águas são potáveis e classificadas como bicarbonatadas cálcicas, onde a concentração em $\mathrm{mEq} / \mathrm{L}$ de $\mathrm{Ca}^{2+}+\mathrm{Mg}^{2+}$ é maior do que a de $\mathrm{Na}^{+}$. As vazões também são as maiores encontradas no município, chegando a $20 \mathrm{~m}^{3} / \mathrm{h}$ e capacidades específicas podendo chegar a $2 \mathrm{~m}^{3} / \mathrm{h} . \mathrm{m}$. Já nas regiões onde o ARB encontra-se confinado, sob influência dos AP, suas águas ficam mais salinizadas, aumentando as concentrações de Sódio e Flúor. Nestas situações, a potabilidade das águas do ARB fica comprometida. Cerca de 30\% dos poços amostrados no município são impróprios para consumo humano, sendo que nas áreas sob influência dos AP, principalmente relacionados à Formação Irati, todos os poços possuem água não potável, principalmente por excesso de Flúor e Sódio.

Uma vez que são necessárias perfurações de poços novos, recomenda-se que os critérios hidroestratigráficos sejam preponderantes na elaboração dos projetos. Nas regiões compreendidas pelas unidades litoestratigráficas da Bacia do Paraná, os poços deverão ser perfurados até o Aquífero Rio Bonito, mesmo que em profundidades maiores . Nas situações em que este aquífero encontrar-se confinado pelos aquitardes permianos, deverão ser instalados filtros somente nas camadas arenosas do ARB, sendo as demais camadas sotopostas isoladas com tubos lisos e cimentação. Também deverão ser realizadas perfilagens geofísicas de poços no momento da perfuração para que sejam isoladas as camadas que contém água salinizada das que contém água mais doce.

Agradecimentos- Os autores agradecem ao CNPq, pelo financiamento deste estudo, e à CPRM pelo apoio logístico prestado na execução do projeto.

\section{Referências}

Almeida, F.F.M. \& Hasui, Y. 1984. O Pré-Cambriano do Brasil. São Paulo, E. Blücher, 378p.

Ben da Costa, A., Lobo, E.A., Kirst, A., Soares, J. \& Goettems, C.H. 2008. Estudo Comparativo da Concentração de Flúor, pH e Condutividade elétrica da Água Subterrânea dos Municípios de Santa Cruz do Sul, Venâncio Aires e Vera Cruz, RS, Brasil. In: CONGRESSO BRASILEIRO DE ÁGUAS SUBTERRÂNEAS, 13, 2008,
Natal. Anais. Natal, ABAS, 1 CD-ROM.

Chemale Jr., F. 2000. Evolução Geológica do Escudo Sul-rio-grandense. In: Holz, M. \& De Ros, L.F. (Eds.) Geologia do Rio Grande do Sul. Porto Alegre, CIGO-UFRGS, p. 13-52.

CONAMA, 2008. Resoluções do CONAMA: Resoluções Vigentes Publicadas entre julho de 1984 e Novembro de 2008. Brasília, DF. 2 ${ }^{\text {a. ed., }}$ 929p.

Frank, H.T., Gomes, M.E.B., Formoso, M.L.L. \& Garcia, G.G. 2007. Contaminação de Flúor dos aquíferos da Bacia do Paraná derivada da desgaseificação de intrusivas da Formação Serra Geral: Nova Hipótese. In: ENCONTRO NACIONAL DE PERFURADORES DE POÇOS, 15, 2007, São Paulo. Anais..., São Paulo, ABAS, 1 CD-ROM.

Freitas, M.A., Lopes, R. C. Goffermann, M., Trein, H.A. \& Gasparini, C. 2010. Utilização da Camada Candiota como guia para prospecção de água subterrânea em Candiota e Hulha Negra-RS. In: CONGRESSO BRASILEIRO DE ÁGUAS SUBTERRÂNEAS, 14, 2010. São Luiz. Anais..., São Luiz, ABAS, 1 CD-ROM.

Gastmans, D. 2007. Hidrogeologia e Hidroquímica do Sistema Aquífero Guarani na Porção Ocidental da Bacia Sedimentar do Paraná. Rio Claro, 238p. Tese de Doutorado, Universidade Estadual Paulista.

Goffermann, M., Viero, A.P. \& Trein, H. 2012. Caracterização Hidrogeológica do Sistema Aquífero Palermo-Rio Bonito na Região Sul do Município de São Gabriel, RS. In: CONGRESSO BRASILEIRO DE ÁGUAS SUBTERRÂNEAS, 17, 2012. Bonito. Anais..., Bonito, ABAS, 1 CD-ROM.

Hausman, A. 1995. Províncias Hidrogeológicas do Estado do Rio Grande do Sul. Acta Geologica Leopoldensia, Série Mapas, 2: 1-127.

Hem, J.D. 1985. Study and Interpretation of Chemical Charac teristics of Natural water. Second Edition. Geologic Survey Water - Supply. Paper 1473, Washington, USA.

Hitchon, B., Perkins, E.H. \& Gunter, W.D. 1999. Intoduction to Ground Water Geochemistry. Alberta, Geoscience Publishing, $310 \mathrm{p}$.

Iglesias, C.M.F. 2000. Análise Integrada de dados Geológicos e Estruturais para a Prospecção de Ouro na Região de Torquato Severo, RS. Porto Alegre, 118 p. Dissertação de Mestrado, Programa de Pós-graduação em Geociências, Instituto de Geociências, Universidade Federal do Rio Grande do Sul.

Kern, M.L., Viero, A.P. \& Machado, G. 2008. The fluoride in the groundwater of Guarani Aquifer System: the origem associeted with black shales of Paraná Basin. Environmental Geology, 55: 1219-1233.

Kircheim, R.E., Goffermann, M. \& Freitas, M.A. 2012. Água Subterrânea na Formação Rio Bonito: Alternativa para atendimento das demandas em assentamentos rurais. In: CONGRESSO BRASILEIRO DE ÁGUAS SUBTERRÂNEAS, 17, 2012. Bonito. Anais..., Bonito, ABAS, 1 CD-ROM

Krebs, A.S.J. 2004. Contribuição ao Conhecimento dos Recursos Hídricos Subterrâneos da Bacia Hidrográfica do Rio Araranguá, SC. Florianópolis, 375 p. Tese de Doutorado, Universidade Federal de Santa Catarina. 
Lavina, E.L. 1991. Geologia Sedimentar e Peleogeografia do Neopermiano e Eotriássico (intervalo Kanzaniano-Scitiano) da Bacia do Paraná. Porto Alegre, 336p. Tese de Doutorado, Curso de Pós-graduação em Geociências, Instituto de Geociências, Universidade Federal do Rio Grande do Sul.

Machado, J.L.F. \& Freitas, M.A. 2005. Projeto Mapa Hidrogeológico do Estado do Rio Grande do Sul. Relatório Final. Porto Alegre, RS: CPRM, 65p. 1 CD - ROM.

Marimon, M.P.C. 2006. O Flúor nas águas subterrâneas da Formação Santa Maria, na região de Santa Cruz do Sul e Venâncio Aires, RS, Brasil. Porto Alegre, 3141p, Tese de Doutorado, Programa de Pós-graduação em Geociências, Instituto de Geociências, Universidade Federal do Rio Grande do Sul.

Marimon, M.O.C., Roisenberg, A. \& Viero, A. P. 2007. Hydrogeochemistry and fluoride origin in groundwater of the Santa Maria Formation, Guarany Aquifer System, Southern Brazil. Hydrogeology Journal, 1: 1-15.

Ministério da Saúde. 2004. Portaria MS no 2914/2011. Brasília, DF: MS, 28 p. Disponível em: http:// portal.saude.gov.br/portal/arquivos/pdf/portaria_2914_2011_pdf.

Nanni, A.S. 2008. O Flúor em águas do Sistema Aquífero Serra geral no Rio Grande do Sul: origem e condicionamento geológico. Porto Alegre, 127p. Tese de Doutorado, Programa de Pós-graduação em Geociências, Instituto de Geociências, Universidade Federal do Rio Grande do Sul.

Nanni, A., Roisenberg, A. Viero, A. \& Marimon, M.P.C. 2009. The hydrochemical facies and anomalous fluoride content in the Serra Geral aquifer system, southern Brazil: a GIS approach with tectonic and principal component analysis. Environmental Geology, 58: 1247-1255.

Naumann, M.P. 1985. Geologia da Região de Ibaré. Porto Alegre, 110 p. Dissertação de Mestrado, Programa de Pós-graduação em Geociências, Instituto de Geociências, Universidade Federal do Rio Grande do Sul.

Piper, A.M. 1944. A graphic procedure in the geochemical interpretation of water-analyses. Transactions of the American Geophysical Union, 25 (6): 914-928.

Roisenberg, C., Formoso, M.L.L., Dani, N., Louber, M. \& Pozoco, E. 2008. Caracterização e evolução geoquímica das águas subterrâneas da mina de Candiota (RS), Brasil. Revista Brasileira de Geociências, 38 (4): 618-628.

Santiago, M.R. \& Silvério da Silva, J.L. 2009. Flúor nas águas subterrâneas: Um Problema Social. In: SIMPÓSIO BRASILEIRO DE RECURSOS HÍDRICOS, 18, 2009, Campo Grande. Anais..., Campo Grande, ABRH, v. 1, p. 1-13.

Schmitt, R.S. 1995. Evolução Tectono-Metamórfica do
Complexo Metavulcano-Sedimentar Coxilha do Batovi, São Gabriel, RS. Porto Alegre, 159 p. Dissertação de Mestrado, Programa de Pós-graduação em Geociências, Instituto de Geociências, Universidade Federal do Rio Grande do Sul.

Schneider, R.L., Muhlmann, H., Tommasi, E., Medeiros, R.A., Daemon, R.F. \& Nogueira, A.A. 1974. Revisão estratigráfica da Bacia do Paraná. In: CONGRESSO BRASILEIRO DE GEOLOGIA, 28, 1974. Porto Alegre, Anais..., Porto Alegre, SBG, v.1, p. 41-65.

Silva Filho, B.C. \& Soliani Jr., E. 1987. Origem e evolução dos Gnaisses Cambaí: Exemplo de estudo integrado de análise estrutural, petro-química e geocronologia. In: SIMPÓSIO SUL-BRASILEIRO DE GEOLOGIA, 2, 1987. Curitiba, PR. Anais..., Curitiba, SBG, v. 1, p.127-146.

Silvério da Silva, J.L., Hirata, R.C.A., Flores, E.L.M. \& Dressler, V.L. 2006. Novas Hipóteses sobre a origem do Flúor no Sistema Aquífero Guarani na depressão central gaúcha. In: CONGRESSO BRASILEIRO DE ÁGUAS SUBTERRÂNEAS, 13, 2006, Curitiba. Anais..., Curitiba, ABAS, 1 CD-ROM.

Stumm, W. \& Morgan, J.J. 1996. Aquatic Chemistry. $3^{\text {a }}$ ed., New York, John Wiley and Sons, 1022p.

Szubert, E.C. \& Toniolo, J.A. 1981. Carvão Energético no Estado do Rio Grande do Sul - Mapeamento Geológico do "Arco" São Gabriel - Bagé. Mapa Geológico do Bloco Rio Santa Maria. Porto Alegre, CPRM, 1 mapa, escala 1:50.000.

Trein, H. 2008. A implicação Antrópica dos Recursos Hídricos Subterrâneos da Bacia Hidrográfica do Rio Urussanga, SC. Rio Claro, 150 p. Tese de Doutorado. Programa de Pós-Graduação em Geociências e Meio Ambiente,Universidade Estadual Paulista.

UFRGS. 1972. Universidade Federal do Rio Grande do Sul. Mapa Geológico do Grau de São Gabriel. Instituto de Geociências, 1 mapa, escala 1:250.000

WHO. 2002. World Health Organization. Environmental Health Criteria. United Nations Environmental Programme, International Labour Organization, World Health Organization, Geneva.

Wildner, W., Ramgrab, G.E.; Lopes, R. da C. \& Iglesias, C.M. da F., 2005. Mapa Geológico do Estado do Rio Grande do Sul. Porto Alegre, CPRM. 1 mapa, escala $1: 750.000$.

Wildner, W., Hartmann, L.A. \& Lopes, R.C., 2007. Magmatism in the Paraná Basin - a new stratigraphic proposal, chemical stratigraphy and geological structures. In: WORKSHOP PROBLEMS IN THE WESTERN GONDWANA GEOLOGY - SOUTH AMERICA - AFRICA, 1, 2007. Gramado, RS, Anais..., Gramado, v. 1, p. 189197. 
